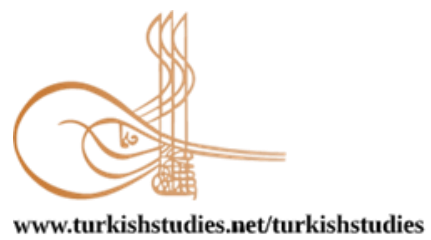

Turkish Studies

\title{
Covid-19 Salgını Nedeniyle Yaşanan Karantina Günlerinde Kadınların Virüs ve Gündelik Yaşamla İlgili Tutum ve Davranışları
}

\author{
Attitude And Behavior Of Women On Virus And Everyday Life In The Quarantine Days Caused By \\ Covid-19 Outbreak
}

\author{
Zekiye Demir ${ }^{*}$ - A. Ömer Toprak ${ }^{* *}$
}

\begin{abstract}
Covid-19 virus is a lethal and high spreading virus from the Corona family that first appeared in China in December 2019. The first case of this virus was recorded on March 11 in our country, and the first death occurred on March 18 caused by virus. A month after the first occurrence of the virus, number of measures have been introduced, such as curfews, intercity, and international travel restrictions, to prevent or reduce the virus from spreading. During these days, which changed the routine of our daily life, distance education and distance working came into our lives; i.e. studying and working from home. People who are under quarantine spent their time at home between four walls in an unknown and unfamiliar length. This study includes following topics during quarantine days of women's lives at home: the use of time spent at home, the effects of the virus on their relationships with family members, what they think about the virüs (their attitudes towards virus), the effects of the virus against news bombardment, the effect of the virus on the use of the phone and social media, the relationship between the virus and religiousness. These issues are generally dealt within the context of women, in particular, housewives and working women. The study was done by quantitative research method. An online Questionnaire was used as a research technique. The questionnaire, which was carried out on the days when the effect of the quarantine days experienced due to the Covid-19 outbreak was actively felt, lasted 10 days. The data of the questionnaire were obtained with the snowball sampling. 1960 women participated in the survey from 77 provinces representing every geographical region having different characteristics. Nearly half of total data was collected from Turkey's three most populous provinces which are Ankara, Istanbul and Izmir. The other half was obtained from other 74 provinces from all over the country. This study was approved to be ethically appropriate by the decision of Ankara Yildırım Beyazit University Ethics Committee dated and numbered 08.10.2020-40.
\end{abstract}

Structured Abstract: A deadly virus belonging to the corona family appeared in China in December 2019 and named as Covid-19 by the World Health Organization. The virus spread to the whole world in a short period of time, in 3-4 months, and turned into a pandemic. The first cases of the virus in Turkey was seen on March 11. Due to the tragedy caused by the virus in China and Italy, the government took series of measures a month after the first case, and introduced quarantine practices by introducing curfews and restrictions.

\footnotetext{
* Prof. Dr., Ankara Yıldırım Beyazıt Üniversitesi, İslami İlimler Fakültesi, Din Sosyolojisi

Prof. Dr., Ankara Yıldırım Beyazıt University, Faculty of Islamic Studies, Sociology of Religion

ORCID 0000-0003-4009-7751

zdemir@ybu.edu.tr

** Dr., Rekabet Kurumu Başkanlığ

PhD., Turkish Competition Authority

ORCID 0000-0002-4874-8486

mraotoprak@gmail.com

Cite as/ Atıf: Demir. Z. \& Toprak, A. Ö. (2020). Covid-19 Salgını nedeniyle yaşanan karantina günlerinde kadınların

virüs ve gündelik yaşamla ilgili tutum ve davranışları. Turkish Studies, 15(6), 391-413.

https://dx.doi.org/10.7827/TurkishStudies.45139

Received/Gelis: 09 July/Temmuz 2020

Accepted/Kabul: 15 October/Ekim 2020

Copyright (C) MDE, Turkey

Checked by plagiarism software

Published/Yayın: 20 October/Ekim 2020

CC BY-NC 4.0
} 
In the quarantine days, work and education started to be remote which turned almost all houses into a school and a working place. In this study, it has been tried to determine the changes in opinions, attitudes, daily life and behaviours of women which was affected by the virus in quarantine days. At the same time, it was tested whether there is statistically significant difference between housewives and working women within the scope of the questions. The findings of the research conducted between 24 April and 4 May, when quarantine days are experienced, can be summarized briefly as follows:

The data of the study consists of the answers of the 1,960 women who participated in the survey. A third of these women are housewives and others are working women.

Looking at the thoughts about Covid-19 virus; the idea that the virus is a warning of God to people is highly participated in both groups of women, but since this rate is higher in housewives, there is a significant difference between housewives and and working women. The rate of participation in the idea that the virus has spread from China is also high, and there is a significant similarity between housewives and women who work. While the participation of women in the opinion that the virus is a biological weapon is nearly half, women who agree with the idea that virüs was produced by drug companies for profit are less than those who do not agree, and working women and housewives show a significant similarity in both of these issues.

In the quarantine days, there were news about the deadly Corona virus, regardless of which TV channel was opened. Against these news, the majority of women can be expected to experience fear and panic, but it has not been realised. In this respect, there is similarity between housewives and working women. Although women do not panic, they are concerned about their close environment, and in this respect there is a significant similarity between home and working women. Again, due to virus news, the vast majority of women stated that they took precautions. However, the rate of measures and incentives of housewives is higher than that of working women, and in the significance test, there was a significant difference between them. In general, when we make an impact assessment, the ratio of women who are not affected and remain calm is two times higher than those affected by Covid-19 news. There is a significant difference in the influence of virus between housewives and working women, and housewives are more affected.

When the food-eating habits in quarantine days are examined; The majority of women say that their eating habits have not changed. However, there are those who say that the number of meals increased among women in a few groups. Again, more than half of the women tried to cook differently on quarantine days, and the different cooking experiences among women differ significantly. Working women have mostly experienced new recipes. Weight gain depends on sedentary life as well as eating and drinking. One-third of women gained weight on quarantine days. There is a similarity between housewife and working women in weight gain.

Although it is assumed that housewives spend most of their time at home, for them, daily life consists of home and non-home areas. Quarantine, like everyone else, has been home-based and home-centered. In terms of time and activities spent at home, there are areas that show similarities and differences in terms of their activities in quarantine days between working women and housewives. In the significance test, subjects with similarities in the time spent at home for both women groups; to watch more news, to help their children lessons, to spend more time on hobbies. Again, the increase in the time spent for household cleaning compared to the days before is among the activities that women show similarity. In terms of the activities carried out at home during the quarantine days, the subjects with significant differences between housewives and working women are; working women slept more, read more books, listened to more music, watched more TV, played more sports at home. Working women turned quarantine days into opportunities for some activities that they could not find opportunities on other days, which changed their sleep patterns more than housewives.

Due to the virus, parents and children spent more time together at home. This can turn into a problem or an opportunity to develop relationships. The quarantine days spent at home within the scope of this study had revealed a positive effect on family relations in terms of both mother-child and husband and wife. This positive effect showed a significant similarity between housewives and working women.

The time spent in social media accounts such as phone and facebook, twitter, whatsapp, and instagram during quarantine days increased among women. However, there is a significant difference in the increase in these two areas among women. Working women made more phone calls and used more social media.

One way of virus protection is to care for cleanliness and hygiene. With public spots, this is often highlighted on TV. The importance of women for hand-face washing and house cleaning has increased in order 
to protect against the virus. It is seen that women care about cleanliness but this does not turn into an obsession. There is no significant difference between housewives and working women in terms of care about cleanliness and not to turn into obsession.

Banned days had an impact on women's shopping habits. The vast majority of women nowadays have reduced their spending. There is no significant difference in reducing the amount of money spent between housewives and working women. In the quarantine days shopping habits, there was no significant difference between working women and housewives in terms of clothing, dry food, but in terms of buying cleaning products. Working women bought more cleaning products. Housewives are more likely to be the first to shop online.

The lethalness of the Covid-19 virus is thought to affect religious attitude and behavior. This research supports this idea. Women thought more about hereafter and death than before, more worshiped, prayed and repented, and did charity work. However, a meaningful difference was found between housewives and working women in terms of these religious attitudes and behaviors, and it was seen that housewives turned to religion more than working women.

During the quarantine days, the vast majority of women missed visiting relatives and friends. Again, those who miss going to shopping malls, eating out, going to cinema-theater are more than those who do not miss. In these aspirations, a difference was observed between working women and housewives in a meaningful way. Working women miss these activities more.

During the quarantine days, where the Covid-19 pandemic has banned going out and caused several restrictions, communities with different professions, education and lifestyles (such as rural or urban living) experienced everyday home life differently from the previous ones. Research reveals that housewives, which constitute an important group among women, differ from working women in terms of many attitudes and behaviors. This research has shown that housewives are different from working women in most of the quarantine period attitudes and behaviors regarding daily life.

Keywords: Covid-19, Coronavirus, Women, Quarantine Days, Life at Home, Epidemic Disease

Öz: Covid-19 virüsü, 2019 yılı Aralık ayında Çin'de ortaya çıkan öldürücü ve yayılma hızı yüksek, Korona ailesinden bir virüstür. Ülkemizde bu virüs ilk vakası 10 Mart’ta kayda geçmiş ve bu virüs sebebiyle ilk ölüm de 17 Martta olmuştur. Virüs vakasının ortaya çıkışından bir ay sonra virüsün yayılmasını önlemek, en azından yavaş yayılmasını sağlamak amacıyla sokağa çıkma, şehirlerarası ve uluslararası seyahat kısıtlamaları gibi bir dizi önlemler alınmıştır. Gündelik hayatın rutinini değiştiren bu günlerde öğrencilerin eğitimi, çalışan insanların işleri evden sürdürülmeye çalışılmıştır. Karantina altındaki insanlar alışık olmadıkları uzunlukta evde ve adeta dört duvar arasında zamanlarını geçirmişlerdir. Bu çalışma karantinanın yaşandığı o günlerde kadınların ev hayatı, evde geçirilen zamanın kullanımı, aile üyeleri ile olan ilişkilerine virüsün etkisi, virüs hakkında neler düşündükleri, virüsle ilgili haber bombardımanı karşında etkilenme durumları, virüsün telefon ve sosyal medya kullanımına etkisi, virüs ile dindarlaşma ilişkisi gibi konuları ele almaktadır. Bu konular genelde kadınlar özelde ise ev kadınları ve çalışan kadınlar bağlamında irdelenmiştir. Çalışma nicel araştırma yöntemi ile yapılmıştır. Araştırma tekniği olarak anket kullanılmıştır. Covid-19 salgını nedeniyle yaşanılan karantina günlerinin etkisinin aktif olarak hissedildiği günlerde internet üzerinden yapılan anket 10 gün sürmüştür. Anketin verisi kartopu örneklemi ile elde edilmiştir. Ankete 1.960 kadın katılmıştır. Katılım Türkiye'nin her bölgesinden ve 77 farklı ilden olmuştur. Toplam verinin yarısı Türkiye'nin en kalabalık ilk üç ili olan Ankara, İstanbul ve İzmir' den toplanmıştır. Diğer yarısı ise bu üç ilin dışında 74 ilden elde edilmiştir. Bu çalışma Ankara Yıldırım Beyazıt Üniversitesi Etik Kurulunun 08.10.2020-40 tarih ve sayılı kararı ile etik açıdan uygun bulunmuştur.

Anahtar Kelimeler: Covid-19, Koronavirüsü, Kadınlar, Karantina Günleri, Evde Hayat, Salgın Hastalık

\section{Giriş}

Normal hayatın akışında her insanın günlük bir rutini bulunmaktadır. Öğrencilerin okulakütüphaneye gidip gelmeleri, ders çalışmaları, yemeleri-içmeleri, arkadaşlarla birlikte olmaları 
günlük rutinlerindendir. Çalışanların işe gidip gelme, iş arkadaşları ile zaman geçirme, sorumlu olduğu işi yürütme veya ev kadınının çocuğunu okula hazırlama, temizlik, ütü, çamaşır gibi ev işleri yapma, yemek pişirme, alışverişe, komşuya, gezmeye gitme gibi gün içinde bir dizi faaliyet günlük hayatın akışı içinde rutinleşir. Bu günlük rutinin kitleler halinde değişmesi ancak o toplumda meydana gelen savaşlar, salgınlar ve devrimler gibi özel şartların sonucu olur. Bir virüsün ortaya çıktığı toplumun sınırlarını kısa zamanda aşarak tüm dünyayı etkileyeceği ve dünyanın rutinini bozacağ 1 , çok da tahmin edilebilir bir durum değildir.

Tarihte zaman zaman kitleleri etkileyen salgın hastalıklar olmuştur; Kara veba, Kolera, Tifüs, İspanyol Gribi, SARS, Domuz Gribi, Ebola bunların en başta gelenleridir. Ancak 2019 yılı Aralık ayında Çin'in Wuhan kentinde ortaya çıkan Covid-19'un tüm bu salgınlar içinde en yayılmacı olanı olduğu söylenebilir. Çıkışından itibaren 5 aylık bir zaman diliminde yaklaşık 120 ülke virüsün etkisi altında kalmıştır. Ülkemiz bu virüs ile virüsün ortaya çıkışından yaklaşık 3 ay sonra yani Mart 2020 'de karşılaştı. Bu aylarda virüs kaynaklı gerek Çin gerekse İtalya'da yaşanan trajik olaylar nedeniyle ilk vakanın görülmesinin ardından bir dizi tedbir alındı. Bu tedbirlerin en etkilisi sokağa çıkma kısıtlaması ve yasaklarının getirilmesiydi. Ülke yönetimi tarafindan hazırlanan kamu spotları, duyuru panolarında bilgilendirme ve yasaklı günlerde dışarı çıkanlara uygulanan cezalar aracığı ile vatandaşların mümkün olduğunca evde kalması sağlanmaya çalışıldı.

Birçok insanın zorunlu evde kaldığı bu dönemde hem evde kalınmasını teşvik etmek hem de kolay hale getirmek için kurum ve kuruluşlar bazı yeni etkinlikler yapmaya çalıştılar. Bu bağlamda müzeler, yayınevleri arşivlerini sanal ortamda paylaştı, sanatçılar evden konserler verdi, film şirketleri ve tiyatrolar gibi pek çok kurum ve kuruluş çevrimiçi içeriklerini kısmen veya tamamen insanların ücretsiz erişimine açtılar. Eğitimin her kademesi uzaktan eğitim yöntemiyle, çalışma hayatı ise mümkün olduğunca evlerden yürütülmeye çalışıldı. Her ne kadar 'virüs hepimizi eşitledi' gibi sloganvari ifadeler kullanılsa da virüs sokağa çıkma açısından kısmen herkesi eşitledi ama dört duvar arasında sürülen yaşantı açısından bazı durumlarda eşitleyici bazı durumlarda da eşitsizliği körükleyici sonuçlar ortaya çıkardı. Çalışan, çalışmayan, öğrenci, ev kadını, yaşı, genç herkes kendi şartları içinde evde kaldıkları karantina günlerinden farklı farklı etkilendiler.

Ev ve eve dair işler genelde kadınla ilişkili olarak daha çok tanımlanır. Erkekle kıyaslandığında ev, adeta kadının uzmanlık alanıdır denilebilir. Ya da öyle görülür. Kadın ister ev kadını olsun ister çalışan kadın ev ve eve dair tüm işleri her gün belirli bir düzen içinde yapar ya da yaptırır, başka bir deyişle evin organizatörü bir şekilde kadınlardır. Bu organizatörlükte diğer kadınlarla daha çok işbirliği yapar, bizzat yapamadıklarını diğer kadınlar yoluyla yaptırırlar. Yani ev odaklı işlerin organizasyonunda organize edilenler de kadınlardır. Bu işlerin en çok göze çarpanı ev temizliği, yemek yapma ve çocuğa bakma olarak sayılabilir. Bunların çoğunu ücretli veya ücret almaksızın çoğu kez bir kadın yapar.

$\mathrm{Bu}$ çalışmanın konusu Covid-19 nedeniyle sokağa çıkmanın, şehirlerarası yolculuğun yasaklandığı ve kısıtlandığı günlerde evde kalan kadınlardır. Amacı ise Covid-19 nedeniyle sokağa çıkma yasak ve kısıtlarının olduğu için birçok kişinin iş-eğitim gibi dışarı faaliyetlerini eve taşındığı bir dönemde ev kadını ve çalışan kadınların gündelik hayatlarının ne ölçüde gündelik dışına taştığını, virüse yönelik kanaatlerinin ne olduğunu ve ölümcül olan bu virüsün dini tutum ve davranışlarının ne ölçüde etkilendiğini ve araştırma soruları kapsamında bu iki grup kadın arasında istatistiksel açıdan anlamlı bir fark olup olmadığını belirlemektir.

$\mathrm{Bu}$ amaca yönelik veri toplamak için nicel araştırma yöntemi anket tekniği kullanılmıştır. Sokağa çıkma kısıtlamalarının ve yasakların olduğu 24 Nisan-4 Mayıs tarihleri arasında mail adresleri, facebook, WhatsApp gibi sosyal medya ile internet üzerinden yapilan, Türkiye'nin her bölgesinden 15 yaş ve üzeri herkesi kapsayan geniş kapsamlı "Korona Günlerinde Evde Hayat" anketine katılan kadınların cevapları bu araştırmanın verisini oluşturmaktadır. Söz konusu alan araştırması çevresinde toplam 4.181 kişiye ulaşılmış, bunlar içinden kadınlar ayrıştırılmıştır. 
Çalışmanın sınırlılığı anketin verisi, araştırmacının çevresinden başlayarak kartopu yöntemi ile oluştuğundan Türkiye'yi temsil iddiası olmamasıdır. Bununla birlikte kadınlar ile ilgili elde edilen veri Türkiye'nin her bölgesinden, 77 farklı ilden toplanmıştır. Toplam verinin yarısı $(\% 50,2)$ Türkiye'nin en kalabalık ilk üç ili olan Ankara, İstanbul ve İzmir'den, diğer yarısı ise bu üç il dışında 74 ilden elde edilmiştir.

Bu kapsamda 1.960 anket incelenmiştir. Bu kadınların 478'i meslek bölümünde 'ev kadın'1 seçeneğini işaretleyen kadınlardır. Diğer 1.482 kadın ise öğrenci seçeneği dışında bir meslek grubu, emekli veya işsiz sekmelerini işaretleyen kadınlardır. Bu durumda ev kadınları diğer kadınların üçte bir oranını oluşturmaktadır. Diğer kadınların yüzde 90'dan fazlasını çalışan kadınlar oluşturmaktadır. Bu nedenle veri, ev kadını ve çalışan kadın olarak iki gruba ayrılmıştır. Anket soruları içinde yer alan evin günlük yemek, temizlik gibi rutinleri ile doğrudan ilgilerinin olmayacağ 1 ve analiz sonuçlarını yanlış yönlendireceği gerekçesiyle öğrenci seçeneğini işaretleyen kadınlar değerlendirmeye alınmamıştır.

\section{Kavramsal Arkaplan}

\section{Ev Kadını - Çalışan Kadın}

Kadınlar ve erkekler tüm tarih boyunca hayatın devamı için birlikte çalışmış, ihtiyaca göre işbirliği veya işbölümü içinde işleri yürütmüşlerdir. Ancak çalışmanın değer veya karşılığı, farklı zaman ve toplumlarda çeşitlilik arz etmiştir. Özellikle sanayileşme, buna bağlı olarak kırsal alandan sanayi bölgelerine göç o zamana kadar çok keskin olmayan bir ayırımı gün yüzüne çıkarmıştır: Çalışma karşıllğı bir ücret alınıp alınmaması çalışmaya atfedilen değeri köklü biçimde değiştirmiştir.

Emeğin ücretle takas edilmeye başlanması birç̧ok sosyo-ekonomik yapıyı, buna bağlı olarak kadın ve erkeğin üretim sürecindeki rolünü ve etkinliğini değiştirmiş, sosyal hayatta karşıllı̆̆ para ile ölçülebilen çalışma (ücretli emek) ile karşılığı olmayan çalışma (ücretsiz emek) ayırımı ortaya çıkmışıtır. Artık giderek çalışma, insanlar için yararlı faaliyetler yapma yerine, evden dışarı çıkma ve 'para kazanma' ile eş anlamı kullanılmaya başlanmıştır. Bu durumda ev içi sorumluluğuna sahip olan ve evde çalışan ancak çalışması karşı1lı̆ında maddi bir getiri elde etmeyen kadınlar 'para kazanamayan', ev dışında çalışıp emeğinin karşılığını maddi olarak alan erkekler 'para kazanan' ve 'eve ekmek getiren' olarak görülmüştür.

Ülkeden ülkeye etkisi farklı olsa da sanayileşme ve savaşlar kadınların evden çıkmasında ve emeklerinin karşılığında ücret alabilmelerinde büyük rol oynamıştır. Özetle geleneksel toplum da denilen tarım toplumundan modern topluma geçişten sonra, son iki yüzyılda küresel denebilecek ölçekte toplumsal değişiminin en önemli göstergelerin birisi kadının ücretli çalışma hayatına katılması olmuştur (Demir, 2020: 205). Para kazanılan işte çalışmakla erkekle kadın arasında oluşan ayırım, bu kez kadınlar arasında oluşmuştur. Bu süreç sonucunda kadınlar için hemen her toplumda geçerli olabilecek bir sınıflama doğmuştur: Ev kadını ve çalışan kadın.

Özellikle öğrenci olmayan kadınlar ya ev kadını veya çalışan kadın olarak iki kategori içinde konumlandırılmaktadır.

Çalışan kadın, yaygın bir anlayışla ev dışında maaş, ücret veya kar adı altında bir parasal karşılık alarak çalışan kadınları nitelemektedir. Yapılan araştırmalar da toplum nezdinde bu anlayışın hakim olduğunu gösterir (Demir, 2020: 34). Çalışan kadın tanımlanırken 'ev dışı' ve 'parasal karşılık' önemli bir vurgu olarak dikkati çeker. Bu durumda ev kadını tanımlanırken eve, ev merkezli faaliyetlere ve parasal karşılık alınmadan yapılan işlere vurgu yapılır.

Çalışan kadınlarla ilgili hem yurtiçinde hem yurtdışında literatürde çok sayıda çalışma mevcuttur. Basit bir internet taramasında bile okuyamayacağınız kadar yerli ve yabancı kaynak bulmak mümkündür. Türkiye'de son yıllarda bu konuda yapılan çalışmalarda en çok başvurulan 
yayınların bazıları olarak; Makal (2010), Özer ve Biçerli (2003), Önder (2013), Kocacık ve Gökkaya (2005) say1labilir.

Ev kadınları dikkate alınmak bakımından çalışan kadınlar kadar şanslı değillerdir. Türkiye'de ev kadınları ile ilgili geniş bir literatür olduğu söylenemez. Odak noktası ev kadınlarının faaliyeti olan en eski çalışmaların başında Ferhunde Özbay'ın "Ev Hanımı" adlı çalışması olduğu söylenebilir (Özbay, 1982). Yine ev kadınları ile ilgili YÖK tez kataloğunu taradığınızda başlığında 'ev kadını' kavramı olan tezler bulunmaktadır. Bunlar genelde tıp, halk sağlı̆̆ı, ev ekonomisi bağlamında çalışılmıştır. Sosyolojik bağlamda çalışan ve ev kadını tanımlamasını, kategorisazyonu ve karşılaştırmasını yapan ve ev kadınlarının günlük deneyimleri ile ilgili en dikkati çeken çalışmalardan biri Ünal'ın çalışmasıdır (2012).

Ev kadını sosyolojinin yeni çalışma alanlarından sayılabilir. Ev kadınını konu alan gerek yurtdışında gerek yurt içinde birçok çalışmaya bakıldığında bir tanım yapma ihtiyacı bile hissedilmemiştir. Özbay (1982: 209) "ev kadınları hakkında bilinenler yetersizdir. Binlerce yıl kadın faaliyetleri bilimin dışında tutulmuş, ihmal edilmiştir" der.

Ev kadını tanımı yapan sözlüklere bakıldığında beklendiği gibi 'ev' ile ilişkilendirilerek tanım yapılmıştır. Türk Dil Kurumu sözlüğüne göre ev kadını "dışarıda herhangi bir işte çalışmayıp kendi ev işlerini gören kadın, ev hanımı" olarak tanımlanmaktadır (TDK, 2020). Cambridge Sözlükte de "Bir evi yöneten ve bir işten para kazanmak yerine çocuk yetiştiren bir kişi” diye ev kadını tarif edilmiştir (Cambridge, 2020).

Ev kadını ile ilgili yapılan tanımlar bazı farklılıklar içermektedir. Hatta Bornstein'e göre (2009: 257) yasalar içinde de farklı tanımlar yapılmaktadır. Buna örnek olarak yasalardan aldığı iki farklı tanımı gösterir. Bunlardan birisi "Ev kadını, ev ve ailenin bakımı birincil sorumluluğu olan ve yaptığı bu iş dolayısıyla doğrudan maddi bir karşılık almayan kişidir", diğeri ise "Yıllarca evde çalışan, aile üyelerine ücretsiz ev hizmeti veren bir kişidir". Ona göre hükümet politikalarına göre bile ev kadını tanımı genişletilip daraltılabilir (Bornstein, 2009: 257).

Ev kadınlarını tek bir kategoride toplamanın güçlüğü tanımlamaların farklı olmasına yol açmıştır (Özbay, 1982: 209; Günay vd., 2014: 40). Bundan dolayı genel geçer bir ev kadını tanımı yapılamamaktadır. Zira ev kadınının görev ve sorumlulukları toplumsal olarak tanımlanır ve bu tanım, farklı · tarihsel dönemlerde ve farklı toplumsal gruplarda değişiklik gösterebilir. Tarım, sanayi ve dijital toplumlarda ev kadını tanımında içerik farklılıkları bulunur. Hatta aynı toplumun farklı yöre ve kültürüne göre de ev kadınının sorumluluğu buna bağlı olarak tanımı değişebilir. Rize Güneyce'de geçimini çay bahçelerinden sağlayan bir toplumda ev kadını olmak ile büyük şehirde bir apartman dairesinde ev kadını olmak arasında fark vardır. Güneyce'deki ev kadınının sorumluluğu sadece ev içi ile sınırlı değildir, çayları kesme, taşıma hatta satma da onun görevleri arasındadır. Yaptığ 1 işten ücret almasa da evin geçimine katkı sağlamaktan sorumludur.

Günümüzde ev kadını tanımında ailenin gelir ve eğitim düzeyi etkilidir. Gelir düzeyi yüksek bir iş adamının karısı ya da kızı olmak ile orta ve alt gelir grubunda birisinin eşi ve kızı olmak aynı anlama gelmez. Ev ile ilgili iki kadın grubu aynı sorumluluğu almaz. Birisi tüm gününü çeşitli dernek veya sivil toplum faaliyetlerinde geçirir, eğlenir ayrıca ev temizliği, yemek yapma gibi ev içi işleri yapmaz, diğeri için aynı durum söz konusu değildir. Ancak kadın ev içi işleri yapsa da birisine yaptırsa da bu işlerin organizesini yapmak sorumluluğu ona aittir. Öyleyse denilebilir ki, ev kadını evin her türlü işinden ve işleyişinden sorumludur. Evden eve değişse de, ev kadını bir evde ne tür işe, hizmete ihtiyaç varsa - ev temizliği, ütü, yemek yapma, çamaşır-bulaşık yıkama, varsa çocuk ve yaşlı bakma vb. - onlardan sorumludur. İzzetbegoviç’in deyimi ile ev kadını ev mühendisidir ve ihtiyaç anında "sağlıkçı, aşçı, pediatrisi, diyetisyen, hijyenist, pedagog, ev bütçesinin ekonomisti, terzi, çiçekçi ve dekoratördür" (İzzetbegoviç 2006: 5- 6). Kısaca ev içi ile ilgili her şeyden sorumludur. Bütün bu bilgilerden hareket ederek şunu diyebiliriz; bütün ev kadınlarını tek bir kategori ile tanımlayamayız ancak bütün ev kadınlarının ortak iki özelliğine vurgu yaparak bir tanım 
denemesinde bulunabiliriz. Ev kadını, kendisi yapsa da başka birine yaptırsa da ev içi iş ve işleyişle ile ilgili sorumluluğa sahip, yerine getirdiği bu sorumluluktan dolayı herhangi bir ücret almayan, talep etmeyen kadındır.

Şunu ilave etmeden geçmenin doğru olmadığı kanısındayız; ilk bakışta kadınlar ev kadını çalışan kadın olarak adlandırılsa da aslında her kadın biraz ev kadınıdır. Zira çalışan kadın çoğu kez evine geldiğinde ev kadınının yaptığı birçok şeyi de yapmaktadır. Kadın çalışsa bile ev işi yapmak, yaptırmak veya düzenlemek onun üzerindedir. Ülkemizde TÜIK' in raporuna göre çalışan kadınlar ev içi işlerde erkeklerden beş kat daha fazla çalışmaktadır (TÜIK, 2015). Bu durum bizim ülkemize özgü olmayıp, dünya genelinde de durum bundan pek farklı değildir. 2016 yılında yayınlanan Uluslararası Çalıșma Örgütünün bir raporunda gelişmişlik düzeyi fark etmeksizin dünya genelinde çalışan kadınların ev işlerinin de eklenmesi ile günlük çalışma saati sürelerinin erkeklerden daha fazla olduğu tespit edilmiştir (Ceylan ve Şahin, 2017: 108).

Ev kadınının günlük yaşamı dikkate alındığında kullandığı zaman 'ev işlerine yönelik' ve 'arta kalan' zaman olarak ikiye ayrılabilir. Arta kalan zaman da ev içinde ve ev dışında kullanılan olmak üzere iki başlık altında ele alınabilir. Ev içinde kullanılan arta kalan zamanlar medya ve sosyal medya (televizyon, radyo, internet, cep telefonu, gazete, facebook, instagram vb.), kitap ve hobiler (el işi, resim, tezhip vb.) gibi faaliyetlere ayrılan zamanlardır. Ev dışında kullanılan arta kalan zamanlar ise akraba-arkadaş gezmeleri, çarşı, pazar, AVM gezintileri, spor, sinema ve tiyatro etkinlikleri gibi faaliyetlerdir (Köse ve Y1lmaz, 2016: 597).

Covid-19 nedeniyle hayatın kısıtlı ve yasaklı olduğu günlerde ev kadınları ile diğer kadınların eşitlendiği nokta, zamanlarını evde geçirmeleri buna bağlı olarak da hem ev işlerinden sorumlu olmaları, hem de arta kalan zamanı ev içinde kullanmalarıdır. Genel bir eşitlenme olsa bile, aşağıda görüleceği üzere bu süreçten kadınlar farklı farklı etkilenmiş̧lerdir.

\section{Gündelik Yaşam}

Sosyal hayatın ve gerçekliğin ifşası olan gündelik yaşam, sosyolojinin çalışma alanlarındandır. Gündelik yaşamın sosyologların gündemine girmesi Birinci Dünya Savaşından sonra, 1920'li yıllara rastlar. Ancak bu konuda literatür oluşmaya başlaması zaman alır. Toplumun var oluşu kadar eski olan bu alana sosyologlar yakın zamana kadar pek ilgi göstermemişlerdir. Sosyolojide gündelik hayatın net bir konum alması 1970'lerden sonra olmuştur, buna rağmen 1970'lerden günümüze kadar gündelik hayat sosyolojisi ile ilgili yapılan incelemeler görece azdır (Kırış, 2019: 133).

Gündelik hayatın tanımlanması pek de kolay değildir. Çünkü gündelik olan zamana göre değişir, dünün gündelik olanı bugün tedavülden kalmış olabilir. Kelime, zamana ve topluma göre sabit değil, değişkendir. Gündelik hayatın dinamizmini oluşturan ilişkiler değişir, zamanla yeni anlayış, kavrayış ve alışkanlıklar oluşur (Köse, 2018: 305).

'Gündelik' kelimesi dar anlamda 'alışılmışı, sıradanı ve rutini' kastediyor olsa bile, bu alışılmış rutinin içinde insanın hayatını sürdürdüğü tüm faaliyetler sayılabilir (Balta, 2018: 53). Bu açıdan bakılınca gündelik hayat bir insanın tüm fiilleri ile ilişki içindedir. Gündelik hayat, insanı insan yapan ve her insana göre değişebilen eylem ve ilişkilerin toplamıdır. Bu demektir ki gündelik hayat bütün günlük faaliyetlerle ilişkilidir (Esgin, 2018a: 19). Gündelik hayatın eylemleri yeniden üretilen pratiklerdir ve insanların hayatı bu pratiklerle inşa edilir (Esgin, 2018b: 388).

Gündelik hayatın pratikleri içine alışkanlıklar, görgü kuralları, giyim-kuşam, dönemin moda anlayışı, boş zaman geçirme yöntemleri, ilişki biçimleri, oyunları, eğlenceleri, ev eşyaları, yemeiçme biçimleri vb. şeyler girer. Böylece hayata dair gerçekleştirilen yeme - içme, barınma, üretim ve tüketim alışkanlıkları, düşünüş şekli, davranış kalıpları başta olmak üzere her türlü etkinlik gündelik hayata dahil edilebilir. Gündelik hayata dair pek çok ayrıntı vardır. Bu ayrıntılar o toplumun yapısını anlamada ve açıklamada önemli bilgi kaynaklarıdır (Elmacı, 2011: 162). 
Gündelik hayata ilişkin her eylem sıradan, alelade, değersiz olarak görünebilir ama sıradan görünen bu eylemler, eylemi gerçekleştirenle kalmaz, başkalarının hayatına da sızar ve etkiler (Ergin, 2018: 343). Mesela yemek yapmak çoğu zaman bir kadın için devamlılık gerektiren, her zamanda ve her toplumda tekrarlanan sıradan gibi görünen gündelik bir eylemdir. Ama yaptığı yemek sadece kendini ilgilendirmez, ailenin diğer bireylerini de etkiler. Yapılan yemek sadece kendisi ile değil diğerleri ile de ilişkilidir. Yine okumak, bir insan için sıradan her gün gerçekleştirdiği bir eylem olabilir ama edindiği bilgi kendisini aşar ve başkanın hayatına sızar, etkiler.

Tanımı çok da kolay olmayan gündelik hayatı çok geniş anlamda zaman ve zeminden bağımsız kişilerin günlük hayatta yapageldiği, başkasının da hayatını etkilediği eylemler bütünü olarak tanımlayabiliriz. İzlenen dizi, uykuda geçirilen süre, yapılan temizlik veya ütü, pişirilen yemek, okunan kitap, çocuk bakımına ya da eşe ayrılan zaman ve sayılabilecek daha birçok şey günlük-gündelik hayatın içinde görülür.

Günlük hayatın akışı kendi mecrasında devam eder. Bu akışı değiştirmek güçlü ideolojik araçlara ihtiyaç duyar. Bu araçlara paralel olarak gündelik hayatı besleyen teknoloji, ekonomi, moda, tüketim, medya gibi unsurlar da ciddi anlamda gündelik hayatın değişim ve dönüşümüne sebep olurlar (Subaşı, 2001: 251 ) Buna ilaveten büyük savaşlar, felaketler hatta bir epidemi veya pandemi haline gelmiş bir virüs de gündelik hayatın akışını değiştirebilir. Bu makale, bir alan araştırması yardımıyla, pandemi haline gelmiş koronavirüsün kısa zaman içinde gündelik yaşama etkisini, Türkiye örneğinde ve kadınlar özelinde ortaya koymaya çalışmaktadır.

\section{COVID-19 (Koronavirüs)}

Koronavirüsler, hayvanlarda veya insanlarda hastalığa neden olabilecek büyük bir virüs ailesidir. Covid-19 bu virüs ailesindendir. Bu yeni tip Koronavirüs hastalığı, ilk olarak Çin'in Wuhan Eyaleti'nde Aralık ayının sonlarında görülmüştür. Ateş, öksürük, nefes darlığı gibi solunum yolu belirtileri gösteren bir grup hastada yapılan araştırmalar sonucunda 13 Ocak 2020'de bu yeni tip virüs Covid-19 olarak isimlendirilmiştir (Sağlı Bakanlığı, 2020a). 2019 yılı Aralık ayında çıkması nedeniyle Koronavirüs ailesinden olan bu virüse Covid-19 denilmiştir.

Wuhan'da teşhis edilen virüs kısa bir süre sonra o bölgede salgın (epidemi) haline dönüşmüş, takip eden günlerde seyahat eden insanların taşıyıcılığı ile tüm ülkeye, ardından diğer ülkelere yayılmıştır (pandemi). 11 Mart 2020 tarihinde Dünya Sağlı Örgütü, 114 ülkede 118 bin vakanın görüldüğünü ve 4 bin 291 kişinin hayatını kaybettiğini açıklayarak Covid-19'un bir pandemi olduğunu ilan etmiştir (BBC News, 2020a). Vaka sayıları ve ölümler her ne kadar çok ciddi rakamlara ulaşmış olsa da hastalığın kaynağının ve yayılma şeklinin bilinmesi, hastalara bakım desteğinin sağlanması vb. açıdan geçmişte yaşanan salgınlarla kıyaslandığında pek çok açıdan daha iyi durumda olunduğunu söyleyen tarihçi ve araştırmacılar da bulunmaktadır (Çitil, 2020: 7).

Avrupa üzerinden gelen bir hastanın test sonuçlarının pozitif çıkması ile ülkemizde ilk Covid-19 vakasına 10 Mart'ta rastlandı. 17 Mart'ta da Covid-19 nedenli ilk ölüm gerçekleşti (Sağlık Bakanlığı, 2020b). Ülkemizde hükümet yetkilileri tarafından Covid-19 vakasına rastlanmadan evvel bilim kurulu kurulmuştu. Dolayısı ile vakanın görülmesinden önce ve sonra tedbirler alındı. Bu erken tedbirlerin alınmasında önce Çin'de ardından İtalya'da virüsün tahribinin tüm trajedileri ile sergilenmesi etkili olmuştur. Virüsle mücadele konusunda erken alınan tedbirler ve uygulanan politika ile ülkemiz diğer birçok ülkeye göre daha başarılı konumdadır.

Türkiye'de günlük hayatı doğrudan etkileyen virüsün yayılmasını önlemek amacıyla alınan tedbirlerden en önemlileri şöyle özetlenebilir: Ortaöğretim ve yükseköğretim başta olmak üzere hemen tüm eğitim kurumlarında uzaktan eğitime geçilmiştir. Sokağa çıkma ve seyahat etme gibi çeşitli yasaklar ve kısıtlamalar getirilmiştir. Bu kapsamda belli yaş gruplarına ve kronik hastalara dışarı çıkma kısıtlaması getirilmiş, dışarı çıkma yasağını ihlal edenlere yüksek bir meblağ sayılacak (3.150 TL) para cezası uygulanmıştır. Seyahat kısıtlamasında; havalimanları yurtdışı uçuşlarına 
kapatılmış, büyükş̧ehir statüsündeki 30 il ile Zonguldak il sınırlarından kara, hava ve deniz yolu ile (toplu ulaşım aracı, özel araç ve yaya vb.) yapılacak tüm giriş/çıkışlar durdurulmuştur (İçişleri Bakanlığı, 2020). Yine tedbirler kapsamında ibadet yerlerinde toplu ibadet yapmaya ara verilmiştir. Mümkün olduğunca kişilerle temas sayısını azaltmak için evden çalışmalar teşvik edilmiştir. Böylece 'Evde kal' çağrıları ile evden eğitim ve evden çalışma hayatı sürdürülmeye çalışılmıştır.

\section{Araştırma Bulguları}

Covid-19 salgını bütün ülkeler için bir kriz dönemi yarattı. Özelde Türk toplumu genelde bütün ülkeler neredeyse eli-kolu bağlı çaresiz bir şekilde devletlerinin alacağı kararları, politikaları ve tedbirleri beklediler. Hükümetlerin bu kapsamda virüsü doğal seyrine bırakmak veya tedbirler ve kısıtlamalar uygulamak gibi politikaları oldu. Ülkemiz de karantina ve kısıtlı yaşam uygulanan ülkelerden birisidir. Salgının ilk ayları olan Nisan-Mayıs aylarında yoğun bir karantina ve kısıtlı yaşam günleri hükümet politikası olarak uygulanmıştır.

Genel olarak insanlar ölümün yıkıcı tehdidi karşısında devlete sığınmıştır. Zira kişiler bireysel olarak pandemik bir salgın karşısında çaresizdir. Bu durumda insanlar bilim insanlarının uyarılarına kulak vermiş, geliştirilecek ilaç teknolojilerinin haberlerini beklemeye başlamış ve iletişim teknolojilerinden yararlanarak gündelik yaşamını sürdürmeye ve kendisini oyalamaya çalışmıştır (Çitil, 2020: 11).

Covid-19 salgını nedeniyle uygulanan 'Evde kal' çağrılarının yapıldığı, virüsle mücadele kapsamında gönüllü ve zorunlu karantina politikalarının uygulandığı dönemlerde evde hayatın ne ölçüde ve hangi alanlarda günlük yaşamın dışına taştığını anket aracılığı ile tespit etmeye çalıştık. Araştırma sorularına verilen cevapların ev kadınları ile diğer kadınlar olarak gruplandırdığımız çalışan, emekli ve iş arayan kadınlar arasında aşağıda belirlenen konularda istatistiksel olarak anlamlı denebilecek bir fark olup olmadığını test ettik. Bu çalışmada ev kadınları ile diğer kadınların;

- Covid-19 hakkındaki düşüncelerinin,

- Covid-19 haberleri karşısında takındıkları çeşitli tutum ve davranışlarının,

- Karantina günlerinde Covid-19'un yemek yapma-beslenme alışkanlıkları üzerindeki çeşitli etkilerinin,

- Covid-19'un karantina günlerinde evde geçirilen zamanda yapılan farklı eylemlere etkisinin,

- Covid-19 nedeni ile yaşanan karantina günlerinde aile bireylerinin uzun zaman dilimini paylaşıyor olmasının aile ilişkilerine etkisinin,

- Covid-19 karantina günlerinin telefon ve sosyal medya kullanımına etkisinin,

- Covid-19'un temizlik ve hijyen alışkanlıklarına etkisinin,

- Covid-19'un alış-veriş yapmaya etkisinin,

- Covid-19'un dini tutum ve davranışlara etkisinin,

- Covid-19 salgını nedeniyle yaşanan karantina günlerinde özlenen şeylerin,

istatistiki olarak anlamlı bir farklılıklarının veya benzerliklerinin olup olmadığı incelenmiştir.

\section{Araştırmanın Örneklem Profili}

Çalışmanın verisini toplam 1.960 kadının görüşleri oluşturuyor. Bunların 478'i $(\% 24,4)$ anketin meslek bölümünde kendini 'ev kadını' olarak ifade eden, 1.482'si $(\% 75,6)$ de çalışan, emekli ve işsiz olarak niteleyen kadınlardır. Ev kadını olmayan \%75,6’nın; \%1,2'sini (24 kişi) işsiz/iş arayan, \%4,7'sini emekli (93 kişi), \%69,7'sini (1.365 kişi) de aktif iş hayatında olan kadınlar oluşturmaktadır.

Ev kadını olmayan kadınlar (1.482 kişi) bir bütün olarak ele aldığınızda bu bütünün \%1,8'ini iş arayanlar, \%6,8'ini emekliler ve \%91,4'ünü aktif çalışanlar oluşturmaktadır. Bu durumda diğer 
kadınlar dediğimizde çoğunlukla çalışan kadınlar olduğu varsayılmıştır. Bu nedenle çalışmanın verisini ev kadınları ve çalışan kadınlar diye iki kategoriye ayırarak değerlendirme yapılmıştır.

Tablo 1: Örneklem Profili

\begin{tabular}{llrr}
\hline Değişken & Parametre & Ev kadın \% & Çalışan kadınlar \% \\
\hline \multirow{4}{*}{ Yaş } & $15-34$ & 29,7 & 37,7 \\
& $35-44$ & 35,4 & 32,3 \\
& $45-54$ & 27,2 & 22,2 \\
& 55 ve üzeri & 7,7 & 8,2 \\
\hline \multirow{5}{*}{ Eğitim Durumu } & Okuryazar & 1,7 & 0,3 \\
& İlköğretim & 21,3 & 0,9 \\
& Lise & 38,3 & 4,5 \\
& Önlisans & 14,9 & 5,0 \\
& Lisans & 22,6 & 56,5 \\
& Master & 1,0 & 18,8 \\
& Doktora & 0,2 & 8,4 \\
\hline \multirow{4}{*}{ Medeni Durum } & Bekar & 2,5 & 34,0 \\
& Evli & 92,7 & 62,3 \\
& Boşanmış/Dul & 4,8 & 3,7 \\
\hline \multirow{5}{*}{ Hane Geliri } & 2.500 ve altı & 24,7 & 5,0 \\
& $2.501-5.000$ & 35,1 & 19,9 \\
& $5.001-7.500$ & 21,1 & 24,0 \\
& $7.501-10.000$ & 10,7 & 25,4 \\
& 10.000 ve üstü & 8,4 & 25,8 \\
\hline \multirow{2}{*}{ Dindarlık Düzeyi } & Hiç ve Az Dindar & 7,1 & 18,0 \\
& Dindar ve Çok Dindar & 92,9 & 82,0 \\
\hline
\end{tabular}

Anket sonuçlarında en alt yaş grubu (15-20) bir üstteki yaş grubuna (21-34) eklenerek 15-34 yaş grubu oluşturulmuştur. Aynı şekilde en üst yaş grubu (65 ve üzeri) bir alttaki yaş grubuna (5564) katılarak 55 ve üzeri yaş grubu yapılmıştır. Dolayısı ile yaş kategorisi 6'dan 4'e düşürülmüştür. Bunun nedeni en alt ve en üstteki grubun istatistiksel yorum yapılamayacak kadar oranlarının düşük olmasıdır.

Ayrıca dindarlık düzeyi de benzer şekilde 'hiç dindar' olmadıklarını ve 'çok dindar' olduklarını belirtenlerin oranları çok düşük olduğundan hiç dindarlar az dindarlara, çok dindarlar da dindarlara dahil edilmiştir. Bu nedenle dindarlık düzeyini 'az dindar' ve 'dindar' olarak iki kategoride ifade edilmiştir.

Özetlemek gerekirse Tablo 1'e bakıldığında araştırmaya katılan ev kadınlarının çoğunluğu evlidir (\%92,7). Günay ve diğerlerinin ev kadınları ile ilgili yaptığı bir çalışmada medeni durum açısından ev kadınlarının oranı \%92,2 çıkmıştır. Bu durumda ev kadını ifadesinden çoğunlukla evli kadınlar varsayıldığ 1 anlamı çıkarılabilir. Yine araştırmamız verilerine göre ev kadınlarının çoğunluğunu 44 yaş ve altı $(\% 65,1)$, lise ve altı eğitimli $(\% 61,3), 5$ bin lira altında hane gelirine sahip $(\% 59,8)$, kendini dindar olarak tanımlayan $(\% 92,9)$ kadınlar oluşturmaktadır. Ev kadını olmayan ve çalışan kadınlar diyeceğimiz grubun çoğunluğunu ise evli $(62,3), 44$ ve yaş altı (\%70), üniversite veya üzeri eğitim yapmış $(\% 83,7), 5$ bin üzeri gelire sahip $(\% 75,2)$ ve dindar $(\% 82)$ kadınlar oluşturmaktadır. 


\section{Covid-19 Hakkında Düşünce, Tutum ve Davranışlar}

İnsanların olaylar ve durumlar hakkında duygu, düşünce, tutum veya davranışları benzerlik ve farklılık gösterebilir. Bunda kişinin yaşadığı coğrafya, hayat koşulları, eğitimi, gelir düzeyi, inancı, cinsiyeti ve bunun gibi faktörler etkili olabilir. Her bir sayılan özelliğin alt özelikleri de mevcuttur. Mesela aynı cinsiyete sahip kişiler cinsiyete dayalı özellikler sergilerken bir taraftan da içinde bulunduğu şartların da etkisi altındadır.

Kadınlar özelliklerine göre olaylar ve olgular hakkında farklı düşünceler, tutum ve davranışlara sahip olabilirler. Bu çalışmada ev kadınları ve çalışan kadınların Covid-19 karantina günlerinde hem virüs hem de çeşitli konularda tutum ve görüşleri arasında farklılık olup olmadığı ele alınd.

İlk olarak tüm dünyayı tehdit eden Covid-19 hakkında ev kadınları ve çalışan kadınların düşünceleri açısından bir farklılık olup olmadığı tespit edilmeye çalışılmıştır.

Tablo 2'ye bakıldığında Covid-19 virüsünün Allah'ın insanlara bir uyarısı olduğunu düşüncesine katılım her iki grup kadında yüksek orandadır. Ancak aralarında 18,3 puanlık bir fark vardır. Ev kadınları çalışan kadınlardan daha fazla oranda virüsün Allah'ın uyarısı olduğu düşüncesine sahiptir. $\mathrm{Bu}$ düşünceye katılım açısında iki grup arasında anlamlı bir farkl1lık $(\mathrm{p}=0,000<0,05)$ olduğu görülmektedir.

Aynı tabloda; Covid-19'un biyolojik bir silah olduğu kanısı açısından ev kadınları ile çalışan kadınlar arasında büyük oranda anlamlı bir benzerlik vardır $(\mathrm{p}=0,737>0,05)$. Her kadın grubu $\% 41$ 42 oranında virüsün biyolojik bir silah olarak hazırlandığı düşüncesindedir. Aynı virüsün bütün dünyaya Çin'den yayılan, tehlikeli bir virüs olduğu düşüncesine katılım yüksektir ve ev kadınları ile çalışan kadınlar arasında yüksek oranda bir benzerlik bulunmaktadır $(\mathrm{p}=0,615)$. Bu iki grup kadında; virüsün büyük ilaç firmalarının kar amaçlı bir oyunu olduğunu ve diğer salgınlardan farksız olduğu ve çok abartıldığı yorumuna katılım oranları düşüktür ve anlamlılık testinde ilki 0,239 , ikincisi 0,635 değeri ile bir benzerlik olduğunu göstermektedir.

Tablo 2: Covid-19 Hakkında Düşünceler (\%)

\begin{tabular}{|c|c|c|c|c|c|}
\hline & & Evet & Hayır & Kararsiz & $\mathrm{p}^{1}$ Değeri \\
\hline \multirow{2}{*}{$\begin{array}{l}\text { Allah'ın insanlara bir uyarısı olduğunu } \\
\text { düşünüyorum. }\end{array}$} & Ev Kadınları & 89,5 & 4,6 & 5,9 & \multirow{2}{*}{, 000} \\
\hline & Çalışan Kadınlar & 71,2 & 15,5 & 13,3 & \\
\hline \multirow{2}{*}{$\begin{array}{l}\text { Biyolojik bir silah olarak hazırlandığını } \\
\text { düşünüyorum. }\end{array}$} & Ev Kadınları & 42,5 & 20,5 & 37,0 & \multirow{2}{*}{,737 } \\
\hline & Çalışan kadınlar & 40,9 & 20,0 & 39,0 & \\
\hline \multirow{2}{*}{$\begin{array}{l}\text { Büyük ilaç firmalarının kar amaçlı bir oyunu } \\
\text { olduğunu düşünüyorum. }\end{array}$} & Ev Kadınları & 27,2 & 35,6 & 37,2 & \multirow{2}{*}{,239 } \\
\hline & Çalışan Kadınlar & 23,5 & 36,4 & 40,1 & \\
\hline \multirow{2}{*}{$\begin{array}{l}\text { Diğer salgınlardan farksız ve çok abartıldığını } \\
\text { düşünüyorum. }\end{array}$} & Ev Kadınları & 14,4 & 66,5 & 19,1 & \multirow{2}{*}{,635 } \\
\hline & Çalışan Kadınlar & 12,8 & 68,1 & 19,1 & \\
\hline \multirow{2}{*}{$\begin{array}{l}\text { Bütün dünyaya Çin'den yayılan, tehlikeli bir virüs } \\
\text { olduğunu düşünüyorum. }\end{array}$} & Ev Kadınları & 78,0 & 6,3 & 15,7 & \multirow{2}{*}{ 615 } \\
\hline & Çalışan kadınlar & 76,9 & 5,6 & 17,5 & \\
\hline
\end{tabular}

Ulusal ve uluslararası medyada Covid-19 virüsünün hızlı bir şekilde yayıldığı, insanların ve ülkelerin bu felaket karşısında hazırlıksız yakalandığı, virüsün binlerce can aldığı, hastanelerin koridorlarında hasta yatırıldığı haberi yer aldı. Yine hastalananların trajik ölümleri, hastalığın çaresinin olmadığı anlatıldı. Virüsle ilgili tüm dünyadan örnekler, üzücü ve dehşete düşürücü haberler de uzun uzun yazılı ve görsel basında yer aldı. Hangi TV kanalı açılsa virüsün tehlikesi ile ilgili bir haberle, programla karşılaşıldı. Birçok insanın psiko-sosyol yönden etkilendiği bu haberler karşısında ev kadınlarının ve çalışan kadınların tutum ve davranışları nasıldı?

\footnotetext{
${ }^{1}$ Pearson Ki-Kare anlamlılık testi değeri. Buna göre; $p<0,05$ olduğunda anlamlı bir farklılık bulunmakta, $p>0,05$ olduğundan anlamlı bir farklılık bulunmamaktadır.
} 
Tablo 3'un sunduğu veriye göre; ev kadınları ve çalışan kadınlar arasında virüs haberleri karşısında 'korku ve panik' hissedenlerin oranı hissetmeyenlerden oldukça azdır. Virüs karşısında korku-panik hissetme açısından her iki grup arasında sınırda bir benzerlik bulunmaktadır $(\mathrm{P}=0,054>0,05)$.

Covid-19 haberleri karşısında 'yakın çevresi ile ilgili kaygıları' olan ev kadınlarının oranı $\% 40,2$, çalışan kadınların oranı ise $\% 44,8$ ' dir. Anlamlılık testi değerlerine $(\mathrm{p}=0,057)$ göre her iki kadın grubunun yakın çevreyle ilgili kaygıları açısından anlamlı bir fark yoktur.

Gelecek bir tehlike karşında tedbir alıp sonra da başına gelecekler konusunda tevekkül etmek olumlu bir insani özelliktir. Hem ev kadınlarının hem de çalışan kadınların büyük bir oranı Covid19 tehlikesi karşısında tedbir alıp tevekkül etmektedir. Ancak aralarında oransal farklılıklar bulunmaktadır. $\mathrm{Bu}$ oranlar anlamlılık testi yapıldığında tedbir alıp tevekkül etme konusunda aralarında anlamlı bir farklılığın $(\mathrm{p}=0,000)$ olduğu görülmektedir. Her iki kadın grubunda da tedbir - tevekkül oranı yüksektir ancak ev kadınlarında bu oran 6,3 puan daha yüksektir. Her ne kadar KiKare anlamlılık testi değeri 5 ten küçük olan hücrelerin bulunduğu tablolarda en güvenilir sonucu garanti etmese de aradaki fark belirgindir (ev kadınları içinde bu soruya hayır diyenlerin sayısı yalnızca 1'dir, çalışan kadınlarda ise 7).

Kadınlar arasında Covid-19 haberleri karşında 'etkilenmeyip sakin kaldım' diyenlerin oranı 'etkilendim, sakin kalmadım' diyenlere göre iki kattan daha fazladır. Ayrıca hem ev kadınları hem de çalışan kadınların açısından bu konuda anlamlı bir farklılık $(\mathrm{p}=0,008)$ bulunmaktadır. Covid-19 haberleri karışında etkilenen ev kadınlarının oranı, çalışan kadınlarından 6,5 puan daha fazladır.

Tablo 3: Covid-19 Haberleri Karşısında Tutum ve Davranışlar (\%)

\begin{tabular}{|c|c|c|c|c|c|}
\hline & & Evet & Hayır & Kismen & p Değeri \\
\hline \multirow{2}{*}{ Korku-Panik hissediyorum. } & Ev Kadınları & 18,6 & 30,1 & 51,3 & \multirow{2}{*}{, 054} \\
\hline & Çalışan kadınlar & 15 & 27,9 & 57,1 & \\
\hline \multirow{2}{*}{ Yakın çevremle ilgili kaygılarım artıyor. } & Ev Kadınları & 40,2 & 15,2 & 44,6 & \multirow{2}{*}{, 057} \\
\hline & Çalışan kadınlar & 44,8 & 11,6 & 43,6 & \\
\hline \multirow{2}{*}{ Tedbirimi alıp- tevekkül ettim. } & Ev Kadınları & 97,7 & 0,2 & 2,1 & \multirow{2}{*}{, 000} \\
\hline & Çalışan kadınlar & 91,4 & 0,5 & 8,1 & \\
\hline \multirow{2}{*}{ Etkilenmiyor, sakin kaliyorum } & Ev Kadınları & 35,2 & 16,5 & 48,3 & \multirow{2}{*}{,008 } \\
\hline & Çalışan kadınlar & 28,7 & 21,7 & 49,6 & \\
\hline
\end{tabular}

\section{Covid-19'un Gündelik Hayata Etkisi}

Felaketler, toplumsal krizler gibi olağan dışı zamanlarda günlük yaşamın örüntüsü değişir. $\mathrm{O}$ zamana kadar günlük hayatın içinde olan ve sıradanlaşan hatta farkına bile varılmayan şeyler, olağan dış1laşan zamanda fark edilmeye başlanır. Hele hele evden çıkmanın yasaklı ve kısıtlı olduğu günlerde yemek yapmanın ayrıntıları, temizliğin incelikleri, uykunun zamanı, kendine ayırdığın kısacık zamanların önemi, o kısa zamanlarda yapıp etiklerinin çeşitliliği daha çok bilinir ve özlenir hale gelir.

Covid-19 nedeni ile ister ev kadını olsun ister çalışan, emekli veya iş arayan tüm kadınların gündelik hayatı nasıl etkilendi? Yemek yapma-beslenme alışkanlığından, evde geçirilen zamanın kullanımına kadar ne tür benzerlik veya farklılaşma olduğu tespit edilmeye çalışılmıştır.

Yemek Yapma-Beslenme. İnsanın hayatını sürdürmek için zorunlu unsurlardan biri beslenmedir. Yemek yapma, doğru ya da yanlış bir beslenme herkesin gündelik hayatının rutini içinde yer alır. Özellikle yemek yapma ev içi hayatta kadının ana sorumluluk alanı olarak görülür. Covid-19 nedeni ile evde kalınan günlerde ev kadınları ile çalışan kadınların yeme-içme alışkanlığg, 
günlük öğün sayısı, değişik yemek yapma deneyimleri benzerlik gösteriyor mu? Evde kalma, günlük aktivitenin azalması ve yeme rutinin değişmesi sonucu kilo alma ve/veya düzenli-sağlıklı beslenme durumu ne ölçüde etkilendi?

Tablo 4'e göre; ev kadınları ve çalışan kadınlarda yeme-içme alışkanlığının etkilenmediğini söyleyenlerin oranı, etkilendiğini söyleyenlerden daha fazladır. Ama bu fark her iki kadın grubu için birbirine yakındır. Bu nedenle ev kadınları ile çalışan kadınlar arasında bir benzerlik bulunmaktadır $(\mathrm{p}=0,210)$. Yine günlük öğün sayım artmadı diyen ev kadınları ile diğer kadınlar arasında bir benzerlik $(\mathrm{p}=0,420)$ vardır. Bir başka deyişle yeme-içme alışkanlığının değişim yönü ve günlük ögün sayısının artış durumu ev kadınları ile çalışan kadınlar için benzerdir.

Karantina nedeniyle dışarıda yaşam geçirme imkanı olmayınca evde kullanılacak zaman çoğalmıştır. Bu zamanın bir kısmını kadınlar mutfakta yeni şeyler deneyerek geçirmiştir. Pandemi sürecinde birçok kadının ilk kez evde ekmek yapmayı denediklerini söyleyerek, pişirdikleri ekmeklerin resmini çeşitli sosyal medya platformlarından paylaştıkları görülmüştür. Ayrıca kadınlar için farklı yemek yapmak zamanı daha eğlenceli geçirme ve sonucu itibariyle takdir alınacak bir faaliyet olarak görülmüştür. Bu kapsamda kadınların yarısı, yeni ve değişik yemek yapmayı denemişlerdir. Ancak oransal olarak çalışan kadınlar \%8,1 oranında ev kadınlarına göre daha çok yeni yemek tarifleri denemişlerdir. Bu nedenle değişik yemek yapmayı deneme açısından ev kadınları ile diğer kadınlar arasında anlamlı bir farklılık vardır $(\mathrm{p}=0,006)$. Yine bu iki grup kadınlar arasında karantina günlerinde düzenli ve sağlıklı beslenme konusunda anlamlı bir farklılık bulunmaktadır $(\mathrm{p}=0,001)$.

Covid-19 virüsü nedeniyle karantina yaşanan günlerde evde zaman geçirmek için daha değişik yemek yapmak, daha hareketsiz bir yaşam sürmek doğal olarak kilo almayı kolaylaştırmıştır. Kadınların yaklaşı üçte biri kilo aldıklarını belirtmişlerdir. Kilo alma açısından ev kadınları ile çalışan kadınlar arasında anlamlı bir benzerlik bulunmaktadır $(\mathrm{p}=0,281)$.

Tablo 4: Karantina Günlerinde Covid-19'un Yemek Yapma-Beslenme Alışkanlıklara Etkisi (\%)

\begin{tabular}{|c|c|c|c|c|c|}
\hline & & Evet & Hayır & Kararsiz & p Değeri \\
\hline \multirow{2}{*}{ Yeme-içme alışkanlığım etkilenmedi. } & Ev Kadınları & 39,5 & 35,8 & 24,7 & \multirow{2}{*}{,210 } \\
\hline & Çalışan kadınlar & 40,8 & 31,6 & 27,6 & \\
\hline \multirow{2}{*}{ Günlük öğün sayım arttı. } & Ev Kadınları & 15,9 & 71,5 & 12,6 & \multirow{2}{*}{,420 } \\
\hline & Çalışan kadınlar & 18,6 & 69,3 & 12,1 & \\
\hline \multirow{2}{*}{ Değişik yemekler yapmayı denedim. } & Ev Kadınları & 46,4 & 34,8 & 18,8 & \multirow{2}{*}{,006 } \\
\hline & Çalışan kadınlar & 54,5 & 27,9 & 17,6 & \\
\hline \multirow{2}{*}{ Kilo aldım. } & Ev Kadınları & 35,4 & 46,2 & 18,4 & \multirow{2}{*}{, 281} \\
\hline & Çalışan kadınlar & 33,6 & 50,2 & 16,2 & \\
\hline \multirow{2}{*}{ Daha düzenli ve sağlıklı beslendim. } & Ev Kadınları & 29,5 & 28,5 & 42,0 & \multirow{2}{*}{, 001} \\
\hline & Çalışan kadınlar & 37,3 & 28,9 & 33,8 & \\
\hline
\end{tabular}

Evde Geçirilen Zaman. Karantina günlerinde insanların zamanla ilişkilerinde bir değişime yaşandığı aşikardır. Covid-19 yasakları ve kısıtlamaları, dışarı merkezli yaşamı ev odaklı yaşama dönüştürmüştür. Bugünlerde; sabah çalar saatle kalkılıp işe-okula yetişmek gibi zorunluluğun olduğu hız odaklı, zamanla yarışılan bir yaşam biçiminden, zamanın yavaş işlediği, koşuşturmacanın azaldığı bir yaşam biçimine geçiş yapılmıştır. Bu yaşamda trafik, yol vs. olmadığından kullanılacak zaman miktarı öncesine oranla görece daha fazladır. Kadınlar bu zamanı nasıl kullanmaktadır, zaman kullanımında ev kadınları ile çalışan kadınlar arasında benzerliğin ve farklılığın olduğu alanlar hangileridir?

Tablo 5'te Covid-19 virüs salgını nedeni ile evde kalınan günlerde ev kadınları ile çalışan kadınların evde geçirdikleri zamanda yaptıkları aktiviteleri karşılaştıran bir dizi faaliyetler bulunmaktadır. Tablo 5'te yer alan faaliyetler için ev kadınları ile çalışan kadınlar arasında anlamlılık 
testi yapıldığında aşağıdaki sonuçlar çıkmıştır. Her iki kadın grubunun evde geçirilen zamanda öncesine göre yaptıkları faaliyetler arasında benzerlik bulunan diğer bir deyişle anlamlı fark bulunmayan eylemler şunlardır; daha çok haber izlemek $(\mathrm{p}=0,240)$, daha çok çocuklarının derslerine yardım etmek $(p=0,485)$, hobilere daha çok zaman ayırmak $(p=0,181)$. Evde yapılan temizlik için harcanan sürenin öncesi günlere göre artması da hem ev kadınları hem de çalışan kadınların benzeștiği faaliyetleri arasındadır ( $\mathrm{P}=0,163)$. Kadınların benzeştiği bir diğer husus da Covid-19'dan öncesine göre zamanı daha verimsiz kullanmadıkları kanısıdır $(p=0,066)$.

Bu sonuçların basit bir gözlemle bile teyit edilmesi mümkündür. Zira virüsün yeni bir olay olması ve evde bu nedenle karantinada kalınması virüsle ilgili haberlere ilgiyi artırmıştır. Ayrıca çocukların eğitimine destek faaliyetleri genelde anneler üzerinden yürümektedir. Uzaktan eğitimin yapıldığı karantina günlerinde eğitimin ilk basamaklarında çocukları olan anneler onların derslerine daha çok yardım etmek zorunda kalmıştır. Mesela anaokulu çağında çocuğu olan bir anne, çocuğunun okulda yapacağı birçok faaliyeti evde kendisi yaptırmak zorunda kalmıştır. Böyle bir anne "Plastik eldivenden inek memesi yapıp süt sağdırdım, çamaşır mandalları ile toplama çıkarma yaptırdım." diyerek evde anaokulu öğretmenliği yaptı̆̆ını anlatmıştır. Yine başka bir anne "Birçok konuyu unutmuşum, önce ben çalışıp sonra çocuğa anlatıyorum geri kalmasın diye" ifadelerini kullanmıştır. Görülüyor ki evde uzaktan eğitim faaliyetlerinde ev kadını ve çalışan kadın fark etmeksizin kadınların çocukların derslerine yardım faaliyetleri benzer şekilde artmıştır.

Karantina günlerinde evde geçilen zamanda yapılan faaliyetler açısından ev kadınları ile çalışan kadınlar arasında anlamlı farklılık bulunan konular şunlardır; çalışan kadınlar daha çok uyumuşlar $(\mathrm{p}=0,000)$, daha çok kitap okumuşlar $(\mathrm{p}=0,000)$, daha çok müzik dinlemişler $(\mathrm{p}=0,000)$, daha çok TV seyretmişler $(\mathrm{p}=0,000)$, daha çok evde spor yapmışlardır $(\mathrm{p}=0,008)$. Anlaşılan çalışan kadınlar sair günlerde firsat bulamadıkları bazı faaliyetler için karantina günlerini fırsata çevirmişlerdir. Bunun için de çalışan kadınların uyku düzeni daha çok karışmıştır $(\mathrm{p}=0,039)$.

Tablo 5: Covid-19'un Karantina Günlerinde Evde Geçirilen Zamana Etkisi (\%)

\begin{tabular}{|c|c|c|c|c|}
\hline & & Evet & Hayır & p Değeri \\
\hline \multirow{2}{*}{ Daha çok uyuyorum. } & Ev Kadınları & 38,8 & 61,2 & \multirow[b]{2}{*}{,000 } \\
\hline & Çalışan kadınlar & 51,2 & 48,8 & \\
\hline \multirow{2}{*}{ Daha çok kitap okuyorum. } & Ev Kadınları & 58,1 & 41,9 & \multirow{2}{*}{, 000} \\
\hline & Çalışan kadınlar & 69,0 & 31,0 & \\
\hline \multirow{2}{*}{ Daha çok müzik dinliyorum. } & Ev Kadınları & 27,5 & 72,5 & \multirow{2}{*}{000} \\
\hline & Çalışan kadınlar & 39,1 & 60,9 & \\
\hline \multirow{2}{*}{ Daha çok TV seyrediyorum. } & Ev Kadınları & 35,6 & 64,4 & \multirow{2}{*}{, 000} \\
\hline & Çalışan kadınlar & 45,1 & 54,9 & \\
\hline \multirow{2}{*}{ Daha çok haber dinliyorum. } & Ev Kadınları & 70,0 & 30,0 & \multirow{2}{*}{, 240} \\
\hline & Çalışan kadınlar & 68,1 & 31,9 & \\
\hline \multirow{2}{*}{ Daha çok evde spor yapıyorum. } & Ev Kadınları & 27,2 & 72,8 & \multirow{2}{*}{,008 } \\
\hline & Çalışan kadınlar & 33,5 & 66,5 & \\
\hline \multirow{2}{*}{$\begin{array}{l}\text { Yeni hobi ediniyorum/hobilerime daha çok zaman } \\
\text { ayırıyorum (el işi, resim, müzik aleti çalma vs.). }\end{array}$} & Ev Kadınları & 41,6 & 58,4 & \multirow{2}{*}{, 181} \\
\hline & Çalışan kadınlar & 44,3 & 55,7 & \\
\hline \multirow{2}{*}{ Daha çok ev işi (temizlik, ütü vs.) yapıyorum. } & Ev Kadınları & 77,4 & 22,6 & \multirow{2}{*}{, 163} \\
\hline & Çalışan kadınlar & 75,0 & 25,0 & \\
\hline \multirow{2}{*}{ Uyku düzenim, gecem-gündüzüm değişiyor } & Ev Kadınları & 47,7 & 52,3 & \multirow{2}{*}{,039 } \\
\hline & Çalışan kadınlar & 52,6 & 47,4 & \\
\hline \multirow{2}{*}{$\begin{array}{l}\text { Öncesinden daha çok çocukların dersine yardım } \\
\text { ediyorum. }\end{array}$} & Ev Kadınları & 51,4 & 48,6 & \multirow{2}{*}{,485 } \\
\hline & Çalışan kadınlar & 51,0 & 49,0 & \\
\hline \multirow{2}{*}{ Zamanımı daha verimsiz kullanıyorum. } & Ev Kadınları & 28,3 & 71,7 & \multirow{2}{*}{, 066} \\
\hline & Çalışan kadınlar & 32,3 & 67,7 & \\
\hline
\end{tabular}

Aile ile İlişkiler. Ailede anne, baba ve çocuklar günlük hayatın koşuşturmasında, zamanla yarış içindedir. Çocukların eğitim, okul, sınav, dershaneler, arkadaş vs., anne-babanın kendine özgü 
hayat telaşları ve sorumlulukları bulunmaktadır. Normal zaman diliminde anne-baba-çocuk üçgeninin aynı anda evde bulunma ve birlikte zaman geçirme süresini oldukça azaltmıştır. Covid-19 nedeniyle ev dışında sosyal hayat için harcanan zamanın son derece azalması hatta neredeyse yok düzeyine gelmesi ailede eş, anne-baba çocuk ilişkisini yoğunlaştırdı. Hatta bunun zaman zaman sosyal medyada espri konusu olduğu görüldü: "Ya bizim hanım baya iyi bir kadınmış", "Hanım evde gezen bu delikanlı kim? Ne! bizim çocuk ne ara bu kadar büyüdü" gibi. Yine evde geçen sürenin artmasına bağlı olarak bazen gazetelerde virüsün boşanmaları artırdığına dair haberler yayınlandı. Söylenen oydu ki; eşler birlikte daha çok zaman geçirince kavgalar, geçimsizlikler, anlaşmazlıklar daha çok artıyordu (Milliyet, 2020).

Araştırmada ulaşılan sonuçlarına göre (Tablo 6) evde kalış ve birlikte zaman geçirme süresinin fazlalaşması aile üzerinde pozitif etki yaratmıştır. Kadınlara göre; aile ile daha çok yakınlaşılmış, evli kadınların eşi ile ilişkisi kuvvetlenmiş, çocuklu kadınlar çocuklarına daha çok zaman ayırmışlar. Hatta gündüz okula gönderdikleri, akşam dersleri ile meşgul olunan çocukları ile gece gündüz evde olup, geçirilen yoğun zamana rağmen çocuklarından bunalmamışlardır. Genelde dünyada çocuk merkezli bir kültürel eğilim mevcuttur (Isık, 2015) özelde ise araştırmaların gösterdiği gibi Türk toplumu çocuğu hayatın merkezine alan bir toplumdur (Pekşen Akça, 2012). Karantina günlerinde de çocukları ile daha çok birlikte olmak aile ilişkilerine olumlu yansımıştır.

Sonuç olarak Covid-19 nedeniyle evde geçirilen karantina günlerinin aile ilişkilerine olumlu etkisi olmuş ve hem çocuk hem de eşler arası ilişkiler konusunda, ev kadınları ile çalışan kadınlar arasında anlamlı bir benzerlik bulunmuştur.

Tablo 6: Covid-19 Nedeni ile Yaşanan Karantina Günlerinin Aile İlişkilerine Etkisi (\%)

\begin{tabular}{|c|c|c|c|c|}
\hline & & Evet & Hayır & p Değeri \\
\hline \multirow{2}{*}{ Ailem ile daha çok yakınlaştım. } & Ev Kadınları & 79,4 & 20,6 & \multirow{2}{*}{,229 } \\
\hline & Çalışan kadınlar & 77,5 & 22,5 & \\
\hline \multirow{2}{*}{ Eşimle ilişkim kuvvetlendi. } & Ev Kadınları & 69,3 & 30,7 & \multirow{2}{*}{,073 } \\
\hline & Çalışan kadınlar & 65,1 & 34,9 & \\
\hline \multirow{2}{*}{ Çocuklara daha çok zaman ayırdım. } & Ev Kadınları & 86,8 & 13,2 & \multirow{2}{*}{, 188} \\
\hline & Çalışan kadınlar & 88,7 & 11,3 & \\
\hline \multirow{2}{*}{$\begin{array}{l}\text { Çocuklarla birlikte olmaktan } \\
\text { bunaldım. }\end{array}$} & Ev Kadınları & 13,1 & 86,9 & \multirow{2}{*}{, 150} \\
\hline & Çalışan kadınlar & 11,0 & 89,0 & \\
\hline
\end{tabular}

Sosyal Medya ve Telefon. Sosyal medyanın faydaları zararları tartışıla dursun her geçen gün etkinliği artmaktadır. Aynı şekilde görüntülü konuşma, bazı uygulamaların ücretsiz konuşma sağlaması da cep telefonu ile konuşma zamanını artırmıştır. Buna evden dışarıya çıkma yasağının eklenmesiyle her zamankinden daha çok sosyal medya kullanımı ve telefon görüşmesi yapıldığını tahmin etmek zor değildir.

Covid19 nedeni ile evde kalınan karantina günlerinde facebook, twitter, whatsApp ve instagram gibi sosyal medya hesaplarında geçirilen zaman hem ev kadınlarında hem çalışan kadınlarda artmıştır. Ancak çalışan kadınlar \%16,7'lik bir farkla ev kadınlarından daha çok sosyal medyaya zaman ayırmıştır. Dolayısı ile sosyal medya kullanımında bu iki grup arasında anlamlı bir fark $(\mathrm{p}=0,000)$ bulunmaktadır. Aynı şekilde telefon görüşmesi süresi tüm kadınlarda artmış ancak çalışan kadınlarda daha çok artmıştır ve bu açıdan da aralarında anlamlı bir fark söz konusudur $(\mathrm{p}=0,027)$ 
Tablo 7: Covid-19 Karantina Günlerinde Telefon ve Sosyal Medya Kullanımı (\%)

\begin{tabular}{|c|c|c|c|c|c|}
\hline & & Evet & Hayır & Kismen & p Değeri \\
\hline \multirow{2}{*}{$\begin{array}{l}\text { Facebook, twitter, whatsapp, instagram } \\
\text { gibi sosyal medya hesaplarımda } \\
\text { geçirdiğim zaman arttı. }\end{array}$} & Ev Kadınları & 40,0 & 30,1 & 29,9 & \multirow{2}{*}{, 000} \\
\hline & Çalışan kadınlar & 56,7 & 19,2 & 24,1 & \\
\hline \multirow{2}{*}{ Telefonla görüşme sürem arttı. } & Ev Kadınları & 44,4 & 30,1 & 25,5 & \multirow{2}{*}{, 027} \\
\hline & Çalışan kadınlar & 49,4 & 24,1 & 26,5 & \\
\hline
\end{tabular}

Temizlik ve Hijyen. Birçok hastalıkla mücadelede temizlik önemli bir araçtır. Özellikle virüslerden korunmada temizlik-hijyen çok önemlidir. Covid-19'la mücadelede temizlik-hijyen, maske ve mesafe vurgusu çok sık yapılmıştır. Ev kadınları ile çalışan kadınların temizlik ve hijyen alışkanlıklarını virüs nasıl etkilemiştir?

Tablo 8'de kadınların daha çok el-yüz yıkadıkları ve daha çok ev-eşya temizliğine önem verdikleri görülmektedir. Ancak ev kadınlarının çoğunluğunda (\%54) temizlik alışkanlıkları pek değişmemiş, çalışan kadınlarda ise (hayır ve kısmeni birlikte ele aldığımızda \%52,7 ile) değişim ev kadınlarına oranla daha fazladır. Ancak her iki grup için de temizlik kaygı ve takıntıya dönüşmemiştir. Her ne kadar temizlik alışkanlığının değişmemesi yönünde genel görüş bulunsa da temizlik kavramının somutlaştıııldığı el-yüz yıkamada belirgin bir artış vardır. Aynı durumun ev temizliğinde geçerli olmadığının gözlenmesi kişisel bir eylem olan el-yüz yıkama pratiğindeki artışın doğrudan virüse karşı bir tedbir olarak algılandığ 1 ama bu durumun genel ev temizliğine yansımadığını göstermektedir. Anlamlılık testi açısından; daha çok el yıkama ( $p=0,681)$, ev ve eşya temizliğine daha çok önem verme $(p=0,228)$ ve buna karşın temizliğin kaygıya dönüşmemesi ( $\mathrm{p}=264)$ açısından ev kadınları ile çalışan kadınlar arasında anlamlı bir fark bulunmamaktadır.

Ancak temizlik alışkanlığının değişmemesi açısından ev kadınları ile çalışan kadınlar arasında anlamlı fark vardır $(\mathrm{p}=0,038)$. Ev kadınları temizlik alışkanlığını daha az oranda değiştirmiştir.

Tablo 8: Covid-19'un Temizlik ve Hijyen Alışkanlıklarına Etkisi (\%)

\begin{tabular}{|c|c|c|c|c|c|}
\hline & & Evet & Hayır & Kismen & p Değeri \\
\hline \multirow{2}{*}{ Temizlik alışkanlığım pek değişmedi. } & Ev Kadınları & 54,0 & 19,7 & 26,3 & \multirow{2}{*}{,038 } \\
\hline & Çalışan kadınlar & 47,3 & 21,9 & 30,8 & \\
\hline \multirow{2}{*}{ Daha çok el-yüz yıkamaya başladım. } & Ev Kadınları & 60,0 & 15,7 & 24,3 & \multirow{2}{*}{,681 } \\
\hline & Çalışan kadınlar & 62,2 & 14,5 & 23,3 & \\
\hline \multirow{2}{*}{$\begin{array}{l}\text { Ev ve eşya temizliğine daha çok önem } \\
\text { vermeye başladım. }\end{array}$} & Ev Kadınları & 51,7 & 19,7 & 28,6 & \multirow{2}{*}{,228 } \\
\hline & Çalıșan kadınlar & 52,3 & 16,5 & 31,2 & \\
\hline \multirow{2}{*}{ Temizlik bende kaygı ve takıntıya dönüştü. } & Ev Kadınları & 12,6 & 68,6 & 18,8 & \multirow{2}{*}{,264 } \\
\hline & Çalıșan kadınlar & 9,9 & 70,5 & 19,6 & \\
\hline
\end{tabular}

Alış - Veriş. İnsanoğlu ihtiyaçlarını önce kendi üreterek daha sonra takas ederek karşılamaya çalışmıştır. Paranın icadından sonra para olduğu müddetçe, hemen tüm ihtiyaçlar para ile giderilme imkanına sahip olundu. Daha sonra ödeme işlemleri banka sistemi üzerinden kredi kartları ve internete taşındi.

Yasaklı günlerde alı̧̧-veriş genelde evin temel yiyecek-içecek-temizlik malzemelerine yönelik olarak yapıldı. Hatta 31 ilde ani bir kararla hafta sonu için sokağa çıkma yasağının ilan edilmesinin ardından market, manav ve firınlara hücum edildiği görüldü (Hürriyet, 2020a). Yasakl1 günlerde sanal marketler de arttı (Hürriyet, 2020b), alış-veriş sanal alana doğru kaymaya başladı. 
Ev ile ilgili özellikle yiyecekler, temizlik malzemesi ayrıca evin mefruşatı, çocukların, bazen eşin ihtiyaçları genelde evin kadını tarafından alınır. Covid-19 nedeniyle yaşanan sokağa çıkma yasaklarının ve kısıtlamalarının olduğu günlerde kadınların alış-veriş ve harcamalarının değişimi ve ev kadınları ile çalışan kadınlar arasında alış-verişte benzerlik, farklılık alanları tespit edilmeye çalışıldı.

Yasaklı günlerin ülke ekonomisine etkisi konumuz dışında kalmaktadır. Ancak aile bütçesinin denkleşmesi üzerinde etkisinin tasarrufu artırma şeklinde olduğu varsayılır. Tablo 9'da görüldüğ̈̈ üzere bu günlerde kadınların büyük çoğunluğunun para harcama miktarı azalmıştır. Üstelik ev kadınları ile diğer kadınlar arasında para harcama miktarının azalması bakımından anlamlı bir farkl1lık yoktur $(\mathrm{p}=0,119)$.

Evde kalınan günler için kuru gıda ve temizlik ürünleri gibi kısa zamanda bozulmayacak şeylere yönelik bir stoklama yapıldığı düşünülebilir. Bu ürünlerin öncesinden daha fazla alınıp alınmadığına bakıldığında araştırmaya katılanların yarısından biraz fazlası böyle bir eyleme girişmediklerini ifade etmişlerdir. Ancak bu davranışta ev kadınları ile çalışan kadınlar arasında anlamlı bir fark bulunmakta $(\mathrm{p}=0,034)$, çalışan kadınların öncesine göre daha çok kuru gıda aldıkları görülmektedir.

Pandemi öncesi ile pandemi dönemi kıyaslandığında, kadınların \%95'inden daha fazlası pandemi döneminde, öncesine göre daha fazla giyim ürünü almadıklarını ifade etmişlerdir. $\mathrm{Bu}$ yüksek orana rağmen ev kadınları ile çalışan kadınlar arasında anlamlı bir farklılık bulunmaktadır $(\mathrm{p}=0,005)$. Çalışan kadınlar normal şartlar altında günün büyük bir kısmını dışarıda geçirdiklerinden, kıyafet ihtiyacı ev kadınlarından daha çok olabilmektedir. İnternetten alış-veriş imkanının olmasıyla karantina günlerinde olsa da çalışan kadınların daha çok giyim ürünü alması anlaşılabilir bir durumdur. Bunun sebebi internetten alışveriş kanallarını çalışan kadınların daha iyi biliyor ve kullanıyor olması da olabilir.

Karantina günlerinde kadınların yarıya yakını daha çok temizlik ürünü aldıklarını belirtmişlerdir. $\mathrm{Bu}$ alış-verişte ev kadınları ile çalışan kadınlar arasında bir benzerlik $(p=0,328)$ bulunmaktadır.

Evde kalınan günlerde internetten alış-verişin artacağı tahmin edilir. Hatta bazıları ilk kez internet alış-verişi tecrübe etmiş olabilir. Bir araştırma firmasının yaptığ çalışmada \%3,6'lık bir kesim karantina sürecinde ilk kez online alışveriş yaptığını belirtmiştir (Metropoll, 2020: 23). Bizim araştırmamıza katılan kadınlar arasında internetten ilk kez alış-veriş yapanlar arasında ev kadınları, çalışan kadınlardan daha fazladır. İlk kez internetten alış-veriş yapma açısından bu iki kadın grubu arasında anlamlı bir farklılık $(0,003)$ bulunmaktadır.

Sonuç olarak, tüm kadınlarda para harcama miktarı azalmış, bu azalmada ev kadınları ile çalışan kadınlar benzerlik göstermiş, yine virüsün etkisiyle temizlik ürünü bu iki grup kadın arasında artmış ve bu artış anlamlı bir benzerlik sergilemiştir.

Tablo 9: Covid-19'un Alış-Veriş Yapmaya Etkisi

\begin{tabular}{|c|c|c|c|c|}
\hline & & Evet\% & Hayır\% & \\
\hline \multirow{2}{*}{ Para harcama miktarım azaldı. } & Ev Kadınları & 71,5 & 28,5 & \multirow{2}{*}{, 11} \\
\hline & Çalışan kadınlar & 74,4 & 25,6 & \\
\hline \multirow{2}{*}{ İlk kez internetten alış-veriş yaptım. } & Ev Kadınları & 14,9 & 85,1 & \multirow[b]{2}{*}{, 00 } \\
\hline & Çalışan kadınlar & 10,0 & 90,0 & \\
\hline \multirow{2}{*}{$\begin{array}{l}\text { Önceden aldığımdan daha çok kuru gıda } \\
\text { aldım. }\end{array}$} & Ev Kadınları & 40,4 & 59,6 & \multirow{2}{*}{03} \\
\hline & Çalışan kadınlar & 45,3 & 54,7 & \\
\hline \multirow{2}{*}{$\begin{array}{l}\text { Önceden aldığımdan daha çok giyim ürünü } \\
\text { aldım. }\end{array}$} & Ev Kadınları & 1,9 & 98,1 & \multirow{2}{*}{5,00} \\
\hline & Çalışan kadınlar & 4,5 & 95,5 & \\
\hline \multirow{2}{*}{$\begin{array}{l}\text { Önceden aldığımdan daha çok temizlik ürünü } \\
\text { aldım. }\end{array}$} & Ev Kadınları & 41,2 & 58,8 & \\
\hline & Çalışan kadınlar & 42,5 & 57,5 & \\
\hline
\end{tabular}


Dine Tutum ve Davranış. Ölüm korkusunun genelde insanları Allah'a yaklaştırdığını gösteren araştırmalar vardır. Yetişkinlerde ölüm korkusu ve dindarlık üzerine yapılan bir araştırmada yaş ilerledikçe yani ölüme yaklaşıldıkça dindarlığın arttı̆̆ı, kadınların erkeklerden daha çok ölüm kaygısı yaşadıkları tespit edilmiştir (Kimer, Köftegül, 2017: 78-79). Yine gözlemlerimize göre inanc1 zayıf da olsa insanların ameliyata girecekken, deprem veya bir afet anında dua ettikleri görülebilmektedir. Buradan çıkarılan sonuç insanlar çaresiz kaldığı ve ölümle yüz yüze geldi durumlarda Allah'tan yardım dileme ihtiyacı hissetmekte ve dini duyguları artmakta, dini duyarlılıkları kuvvetlenmektedir.

Covid-19 tedavisi bulunmayan ve kitlelerin ölümüne neden olan ve tüm dünyayı tehdit eden son derece tehlikeli bir virüstür. $\mathrm{Bu}$ virüs karşısında kendini çaresiz hisseden insanların ibadethanelerde; Vatikan'da (BBC News, 2020b), Mescit-i Aksa'da (Yeni Şafak, 2020), Türkiye'de camilerde (Hürriyet, 2020c) hastanelerde (Sabah, 2020) topluca dua ettikleri ile ilgili onlarca haber servis edilmiştir. Buradan açıkça anlaşılmaktadır ki, ölüm tehlikesinin olduğu durumlarda dini tutum ve davranışta bir artış olmaktadır.

Tablo 10'a bakıldığında kadınların çoğunluğunda Covid-19 nedeni ile dini duyarlık, dini ilgi, tutum ve davranışta bir artış olduğu görülmektedir. Bu artışın ev kadınları ile çalışan kadınlar arasındaki anlamlılık değerine baktığımızda; ahireti ve ölümü daha sık düşünme $(p=0,000)$, namazoruç gibi ibadete daha çok yönelme $(p=0,000)$, Allah'a daha çok dua etme $(p=0,000)$, hayatı ve hataları düşünerek daha çok tövbe etme $(\mathrm{p}=0,000)$ ve daha çok hayırda (sadaka-yardım) bulunma $(\mathrm{p}=0,009)$ açısından iki grup kadın arasında anlamlı bir farklılık belirlenmiştir. Bu tutum ve davranışların her birinde (ahiret ve ölümü daha sık düşünme, namaz-oruç gibi ibadetlere daha çok yönelme, Allah'a dua etme, tövbe etme, sadaka verme-yardım etme) ev kadınlarının oranı çalışan kadınlardan daha yüksektir. Bu durumda şu sonuca varılabilir, Covid-19 bütün kadınlarda dini duyarlığı artırmış ancak ev kadınlarında daha çok artırmıştır.

Tablo 10: Covid-19 Dini Tutum ve Davranışlara Etkisi (\%)

\begin{tabular}{|c|c|c|c|c|}
\hline & & Evet & Hayır & p Değeri \\
\hline \multirow{2}{*}{ Ahireti ve ölümü daha sık düşündüm. } & Ev Kadınları & 88,7 & 11,3 & \multirow{2}{*}{, 000} \\
\hline & Çalışan kadınlar & 70,0 & 30,0 & \\
\hline \multirow{2}{*}{ Namaz-oruç gibi ibadetlerimde artış oldu. } & Ev Kadınları & 69,7 & 30,3 & \multirow{2}{*}{, 000} \\
\hline & Çalışan kadınlar & 55,6 & 44,4 & \\
\hline \multirow{2}{*}{ Allah'a daha çok dua ettim. } & Ev Kadınları & 94,4 & 5,6 & \multirow{2}{*}{, 000} \\
\hline & Çalışan kadınlar & 83,1 & 16,9 & \\
\hline \multirow{2}{*}{$\begin{array}{l}\text { Hayatımı ve hatalarımı düşünerek daha çok } \\
\text { tövbe ettim. }\end{array}$} & Ev Kadınları & 89,1 & 10,9 & \multirow{2}{*}{, 000} \\
\hline & Çalışan kadınlar & 72,9 & 27,1 & \\
\hline \multirow{2}{*}{$\begin{array}{l}\text { Daha çok } \\
\text { bulundum. }\end{array}$} & Ev Kadınları & 70,1 & 29,9 & \multirow{2}{*}{,009 } \\
\hline & Çalışan kadınlar & 64,1 & 35,9 & \\
\hline \multirow{2}{*}{$\begin{array}{l}\text { Dine olan } \\
\text { değişmedi. }\end{array}$} & Ev Kadınları & 78,2 & 21,8 & \multirow[t]{2}{*}{, 178} \\
\hline & Çalışan kadınlar & 76,0 & 24,0 & \\
\hline
\end{tabular}

Karantina Günlerinde Özlenenler. Gündelik hayatın içinde yapa gelinen şeyler yapılamaz olduğunda özlenebilir. Bu şeylerin özlenme derecesi aynı zamanda hayatımızdaki önemini de gösterir. Covid-19 nedeniyle sokağa çıkma yasaklarının ve kısıtlamalarının olduğu günlerde akrabaarkadaş ziyaretleri, AVM'lere gitme ve orada alış-veriş yapma, ev dışında bir kafede, lokantada yemek-içmek, sinema-tiyatro gibi kültür ve eğlence içeren yerlere gitme kadınların hayatında ne kadar önemli ne kadar özlendi? Ev kadınları ile çalışan kadınlar arasında bu bunları özlemede anlamlı bir benzerlik veya farklılık var midır? 
Tablo 11'e bakıldığında aile, akraba, arkadaş, komşu ziyaretlerini kadınların büyük çoğunluğu özlediğini ifade etmiştir. Bu sonuçlara göre 100 kadından ortalama sadece 4'ü bu ziyareti özlemediğini bildirmiştir. Bu sonuç, genelde ayrım olmaksızın tüm kadınlar için bu tür ilişkilerin önemini de vurgulamaktadır. Ancak çalışan kadın ev kadını ayrımı yönüyle konu ele alındığında iki kadın grubu için bu ziyaretler konusunda evet diyenler neredeyse aynı oranda iken, ayrışmanın hayır ve kısmen cevabı arasındaki geçişkenlikten kaynaklandığı açıktır. Bundan dolayı denebilir ki en azından hayır ve kısmen cevabı verenler açısından aralarında anlamlı bir farklılık vardır $(\mathrm{p}=0,005<0,05)$.

Kadınların arasında AVM'lere gitmeyi ve orada alış-veriş yapmayı, dışarda yemek yiyip, çay kahve içmeyi, sinema ve tiyatroya gitmeyi özleyenler özlemeyenlere göre çoğunluktadır. Ev kadınları ile çalışan kadınlar arasında bunları özleme açısından anlamlı bir fark bulunmaktadır. Bu aktivitelerin hepsini özlemede çalışan kadınlar oran olarak ev kadınlarından daha fazladır.

Tablo 11: Covid-19 Salgını Nedeniyle Yaşanan Karantina Günlerinde Özlenen Şeyler (\%)

\begin{tabular}{|c|c|c|c|c|c|}
\hline & & Evet & Hayır & Kismen & p Değeri \\
\hline \multirow{2}{*}{$\begin{array}{l}\text { Aile, akraba, arkadaş, } \\
\text { ziyaretlerini özledim. }\end{array}$} & Ev Kadınları & 83,8 & 2,5 & 13,7 & \multirow{2}{*}{, 005} \\
\hline & Çalışan kadınlar & 83,5 & 5,8 & 10,7 & \\
\hline \multirow{2}{*}{$\begin{array}{l}\text { AVM'ye gitmeyi/ rahat alış-veriş } \\
\text { yapmayı özledim. }\end{array}$} & Ev Kadınları & 40,8 & 35,9 & 23,3 & \multirow{2}{*}{, 025} \\
\hline & Çalışan kadınlar & 46,3 & 29,3 & 24,4 & \\
\hline \multirow{2}{*}{$\begin{array}{l}\text { Dışarda yeme-içmeye (çay, kahve, } \\
\text { vs.) gitmeyi özledim. }\end{array}$} & Ev Kadınları & 42,7 & 31,8 & 25,5 & \multirow{2}{*}{, 000} \\
\hline & Çalışan kadınlar & 57,3 & 18,8 & 23,9 & \\
\hline \multirow{2}{*}{ Sinema-tiyatroya gitmeyi özledim. } & Ev Kadınları & 37,6 & 34,5 & 27,9 & \multirow{2}{*}{, 000} \\
\hline & Çalışan kadınlar & 51,9 & 25,3 & 22,8 & \\
\hline
\end{tabular}

\section{Sonuç}

Korona ailesine ait ölümcül bir virüs 2019 yılı Aralık ayında Çin'de ortaya çıkmış bu nedenle bu virüse Covid-19 denilmiştir. Virüs önce ülke içinde sonra da 3-4 ay gibi kısa bir sürede tüm dünyaya yayılarak pandemiye dönüşmüştür. Türkiye'de ilk virüs vakası 10 Mart’ta görülmüştür. Çin'de ve İtalya'da virüsün yol açtığı trajedi nedeniyle hükümet ilk vakadan bir ay sonra bir dizi önlemler almış, bu kapsamda sokağa çıkma yasakları ve kısıtlamaları getirerek karantina uygulamasına başlamıştır.

Karantina günlerinde eğitimin uzaktan olması ve uzaktan iş hayatının yürütülmeye çalışılmasıyla çoğu ev, okul ve işyeri niteliği görmeye başlamıştır. Bu çalışmada karantinada evde kalan kadınların virüse yönelik kanaatleri, tutumları, ölümcül olan bu virüsün dini tutum ve davranışlarını ne ölçüde etkilendiği, evde yaşamda günlük hayatın daha önceye oranla nasıl değiştiği, nelerin özlendiği tespit edilmeye çalışılmışıı. Aynı zamanda ev kadını ile çalışan kadınlar arasında sorular kapsamında istatistiki olarak anlamlı bir fark olup olmadığını test edilmiştir. Karantina günlerinin yaşandığı 24 Nisan-4 Mayıs tarihleri arasında yapılan araştırmanın bulguları kısaca şöyle özetlenebilir:

Çalışmanın verisini ankete katılan 1.960 kadının cevapları oluşturmaktadır. Bu kadınların üçte birini ev kadınları diğerlerini çalışan kadınlar oluşturmaktadır.

Covid-19 virüsü hakkındaki düşüncelere bakıldığında; virüsün Allah'ın insanlara bir uyarısı olduğu düşüncesine katılma, her iki grup kadında yüksek orandadır, ancak ev kadınlarında bu oran daha yüksek olduğundan çalışan kadınlarla aralarında anlamlı bir fark bulunmaktadır. Virüsün Çin'den yayıldığı düşüncesine katılma oranı da yüksektir ve bu konuda ev kadınları ile çalışan kadınalar arasında anlamlı bir benzerlik söz konudur. Virüsün biyolojik bir silah olduğu kanısına kadınların katılımı yarıya yaklaşırken, ilaç firmalarının kar amaçlı bu virüsü ürettiği fikrine katılan 
kadınlar katılmayanlardan daha azdır ve bu iki konuda da ev kadınları ile çalışan kadınlar anlamlı bir benzerlik göstermektedir.

Karantina günlerinde hangi TV kanalı açılsa ölümcül koronavirüsü ile ilgili haberlere rastlanmaktadır. Bu haberler karşında kadınların çoğunluğunun korku ve panik hali yaşaması beklenebilir. Ancak virüsle ilgili kadınlar korkuya ve paniğe kapılmamıştır. Bu açıdan ev kadınları ile çalışan kadınlar arasında zayıf da olsa benzerlik bulunmaktadır. Kadınlar paniğe kapılmasalar da yakın çevreleri ile ilgili kaygılanmışlar ve bu açıdan da ev ve çalışan kadınlar arasında anlamlı bir benzerlik vardır. Yine virüs haberlerinden dolayı kadınların büyük çoğunluğu tedbir alıp tevekkül ettiklerini belirtmişlerdir. Ancak ev kadınlarının tedbir ve tevekkül oranı çalışan kadınlardan daha fazladır ve anlamlılık testinde bu konuda aralarında anlamlı bir fark olduğu görülmüsstür. Genel olarak etkilenme değerlendirmesi yaptığımızda kadınlardan Covid-19 haberleri karşında 'etkilenmeyip sakin kalanların' oranı etkilenenlerden iki kat daha fazladır. Ev kadınları ile çalışan kadınlar arasında etkilenmede anlamlı bir fark bulunmakta ve ev kadınları daha çok etkilenmektedir.

Karantina günlerinde kadınların yemek yapma-beslenme alışkanlıkları irdelendiğinde; az sayıda kadınların öğün sayısının arttığı, kadınların çoğunluğunun yeme içme alışkanlığının değişmediği tespit edilmiştir. Yine karantina günlerinde kadınların yarısından fazlası değişik yemek yapmayı denemişler ve kadınlar arasında değişik yemek yapma deneyimi anlamlı derecede farklılık göstermektedir. Çalışan kadınlar daha çok yeni yemek tarifleri deneyimlemişlerdir. Kilo alma yeme içmeye bağlı olduğu kadar hareketsiz yaşama da bağlıdır. Kadınların üçte biri karantina günlerinde kilo almıştır. Kilo alma konusunda ev kadını ve çalışan kadınlar arasında anlamı bir benzerlik bulunmaktadir.

Her ne kadar ev kadınlarının zamanın büyük bir bölümünü evde geçirdiği varsayılsa bile onlar için de günlük hayat ev ve ev dış1 alanlardan oluşmaktadır. Karantina günlerinde herkes gibi kadınların da günlük yaşamı evden ibaret, ev merkezli olmuştur. Evde geçirilen zaman ve faaliyetler açısından ev kadınları ile çalışan kadınların öncesi günleri ile karantina günleri kıyaslandığında hem benzerlik gösteren hem de farklılık gösteren alanlar bulunmaktadır. Anlamlılık testinde her iki kadın grubun için evde geçirilen zaman hususunda benzerlik bulunan konular; daha çok haber izlemek, daha çok çocuklarının derslerine yardım etmek, hobilere daha çok zaman ayırmaktır. Yine evde yapılan temizlik için harcanan sürenin öncesi günlere göre artması kadınların benzerlik gösterdiği faaliyetler arasındadır. Karantina günlerinde evde geçilen zamanda yapılan faaliyetler açısından ev kadınları ile çalışan kadınlar arasında anlamlı farklılık bulunan konular ise; çalışan kadınlar daha çok uyumuşlar, daha çok kitap okumuşlar, daha çok müzik dinlemişler, daha çok TV seyretmişler ve daha çok evde spor yapmışlardır. Çalışan kadınlar sair günlerde fırsat bulamadıkları bazı faaliyetler için karantina günlerini firsata çevirmişler bu da uyku düzenlerini ev kadınlarına göre daha çok değiştirmiştir.

Koronavirüs nedeni ile eş- anne baba çocuk virüs öncesi zamanla kıyaslandığında, evde daha uzun süre birlikte zaman geçirmişlerdir. $\mathrm{Bu}$ durum soruna veya ilişkileri geliştirmede firsata dönüşebilir. Bu çalışma kapsamında evde geçirilen karantina günlerinin hem anne-çocuk hem karıkoca açısından aile ilişkilerine olumlu etkisi olmuştur. Bu olumlu etki ev kadınları ile çalışan kadınlar arasında anlamlı bir benzerlik göstermiştir.

Karantina günlerinde telefon ve facebook, twitter, whatsapp, instagram gibi sosyal medya hesaplarında geçirilen zaman kadınlar arasında artmıştır. Ancak kadınlar arasında bu iki alandaki artışta anlamlı bir fark bulunmaktadır. Çalışan kadınlar daha çok telefon görüşmesi yapmış ve daha çok sosyal medya kullanmışlardır.

Virüsten korunmanın bir yolu temizlik ve hijyene önem vermektir. Kamu spotları ile bu sık sık TV'de vurgulanmıştır. Virüsten korunmak için kadınların el-yüz ve ev temizliğine verdikleri önem artış göstermiştir. Kadınların temizliğe önem verdiği ancak bunun temizlik takıntısına 
dönüşmediği görülmektedir. Temizliğe önem verme ve temizliğin takıntıya dönüşmemesi açısından ev kadınları ile çalışan kadınlar arasında anlamlı bir fark yoktur.

Yasaklı günlerin bir etkisi de kadınların alış-verişi üzerinde olmuştur. Kadınların büyük bir çoğunluğunun bu günlerde para harcama miktarı azalmıştır. Ev kadınları ile çalışan kadınlar arasında para harcama miktarının azalmasında anlamlı bir fark yoktur. Karantina günlerinde yapılan alışverişte giyim, kuru gıda açısından çalışan kadın ve ev kadını arasında anlamlı bir fark bulunmamış, ancak temizlik ürünleri alma açısından fark bulunmuştur. Çalışan kadınlar daha çok temizlik ürünü almıştır. İlk kez internetten alış-veriş yapanlar arasında ev kadınları daha çoktur.

Covid-19 virüsünün ölümcül olmasının dini tutum ve davranış1 etkileyeceği düşünülür. $\mathrm{Bu}$ araştırma bu düşünceyi desteklemektedir. Kadınlar öncesine göre daha çok ahireti ve ölümü düşünmüş, ibadet yapmış, dua ve tövbe etmiş, hayır işleri yapmışlardır. Ancak ev kadını ile çalışan kadın arasında bu dini tutum ve davranışlar açısından anlamı bir fark bulunmuş, ev kadınlarının çalışan kadınlardan daha çok dine yönelmiş olduğu görülmüştür.

Evde geçirilen yasaklı ve kısıtlı günlerde kadınların büyük çoğunluğu akraba, arkadaş ziyaretlerini özlemiştir. Yine AVM'lere gitmeyi, dışarda yeme içmeyi, sinemaya-tiyatroya gitmeyi özleyenler özlemeyenlerden daha fazladır. Bu özlemlerde anlamlı bir şekilde çalışan kadınlar ile ev kadınları arasında fark gözlenmiştir. Çalışan kadınlar bu faaliyetleri daha çok özlemiştir.

Covid-19 salgını nedeniyle dışarı çıkma yasak ve kısıtlamalarının bulunduğu karantina günlerinde farklı meslek, eğitim ve yaşam tarzına sahip (kır veya kentte yaşama gibi) toplum kesimleri gündelik ev hayatını birbirinden değişik ve her biri de öncekilerden daha farklı biçimde tecrübe etmişlerdir. Araştırmalar kadınlar içinde önemli bir grubu oluşturan ev kadınlarının birçok tutum ve davranış yönünden çalışan kadınlardan farklılaştığını ortaya koymaktadır. Bu araştırma ev kadınlarının karantina döneminde gündelik hayata dair tutum ve davranışların bir çok alanda çalışan kadınlardan farklı olduğunu göstermiştir.

\section{Kaynakça}

Balta, E. (2018). Marxizm, ütopya ve gündelik hayat, İçinde: Gündelik Hayat Sosyolojisi. (Ed. A. Esgin ve G. Çeğin) Phoenix, 53-68.

BBC News (2020a). https://www.bbc.com/turkce/haberler-dunya-51614548 (erişim:31.05.2020).

BBC News(2020b). https://www.bbc.com/turkce/haberler-dunya-51789323 (erişim: 30.06.2020).

Bornstein, L.C. (2009). Homemakers and social security: giving credits where credits are due, Wisconsin Journal of Law, Gender \& Society, 24, 256-275.

Cambridge (2020). Homemaker, https://dictionary.cambridge.org/dictionary/english/homemaker (erişim: 31.05. 2020).

Ceylan, S. ve Yılmaz Şahin, B. (2017). Demokrasi ve kadınların iş gücüne katılımı: panel veri analizi, İçinde: Yönetim ve Organizasyon Makaleleri, (Haz. E. Gökçen Kaygısız ve R. A. Wolff), Giresun: Eğitim Yayınevi, 107-118.

Demir, Z. (2020). "Işs"te kadın. Dindarlık çalışma hayatı ve kadın. Sentez Yayıncılık.

Elmacı, T. (2011). Taşrada gündelik hayatın ideolojisinin vavien ve süt filmleri perspektifinden okunmas1, Selçuk İletişim, 7(1), 161-173.

Ergin, N. B. (2018). Sıradan insanların gündelik sanatları: de certeau ve gündelik hayat, İçinde: Gündelik Hayat Sosyolojisi. (Ed. A. Esgin ve G. Çeğin) Phoenix, 343-370. 
Esgin, A. (2018a). Gündelik hayat sosyolojisi: tarihsel süreç ve temel ilkeler, İçinde: Gündelik Hayat Sosyolojisi. (Ed. A. Esgin ve G. Çeğin) Phoenix,13-34.

Esgin, A. (2018b). Anthony Giddens: Yapılaşma alanı olarak gündelik hayat, İçinde: Gündelik Hayat Sosyolojisi. (Ed. A. Esgin ve G. Çeğin) Phoenix, 371-404.

Günay, G., Aydıner Boylu, A. ve Bener, Ö. (2014). Ev Kadınlarının Sosyal Güvenlik Sistemine İlişkin Görüşleri, Sosyal Güvenlik Dergisi, 4(1). 35-58.

Hürriyet (2020a).https://www.hurriyet.com.tr/galeri-sokaga-cikma-yasagini-duyanlar-akin-ettimetrelerce-kuyruk-olustu-41491950 (erişim: 29.06.2020).

Hürriyet (2020b). https://www.hurriyet.com.tr/kesfet/sen-evde-kal-market-sana-gelsin-onlinemarketler-hakkinda-bilmeniz-gereken-her-sey-41473809 (erişim: 29.06.2020).

Hürriyet, (2020c). https://www.hurriyet.com.tr/gundem/camilerde-corona-virusun-son-bulmasiicin-dua-edildi-41476100 (erişim: 30.06.2020).

Isık, S. Y. (2015). Küresel kültürel değişim ve 'yeni' annelik: ankara kamil ocak mahallesi örneği, Eğitim Bilim Toplum Dergisi,13(50), 48-75.

İzzetbegoviç, A. (2006). Müslüman kadın - kadın ve anne (İslâm'daki kadın meselesinin araştırılmasına bir katkı), Çev. R. Ademi, Haz. M. H. Akın-F. Karaaslan-Ü. Aktaş, Malatya Büyükşehir Belediyesi Yayınları.

Kırış, E. (2019). Fransız sosyoloji'sinde gündelik hayat çalışmaları, Sosyal ve Kültürel Araştırmalar Dergisi, 5(9), 131-145.

Kimter, N., Köftegül, Ö. (2017). Yetişkinlerde ölüm kaygısı ile dindarlık arasındaki ilişki üzerine bir inceleme, Journal of Sakarya University Faculty of Theology (SAUIFD), XIX (36), 55-82.

Kocacık, F., Gökkaya, V. B. (2005). Türkiye'de çalışan kadınlar ve sorunları, C.Ü. İktisadi ve İdari Bilimler Dergisi, 6 (1), 195-219.

Köse, H. (2018). Yaban bilinç ya da Lefebvre'e göre gündelik hayat, İçinde: Gündelik Hayat Sosyolojisi. (Ed. A. Esgin ve G. Çeğin) Phoenix, 305-341.

Köse, N., Yılmaz, H. (2016). Serbest zaman ve ev kadınları: Nevşehir örneği, Turkish Studies, 11(21), 597-604.

Makal, A. (2010).Türkiye'de erken Cumhuriyet Dönemi’nde kadın emeği, Çalışma ve Toplum, sayı:25, $13-41$.

Metropoll (2020), Türkiye'nin nabzı. türkiye'nin koronavirüs ile sınavı. Nisan 2020 Raporu.

Milliyet (2020). https://www.milliyet.com.tr/corona-virus-cin-de-bosanmalari-neden-arttirdi-molatik-14524/ (erişim: 29.06. 2020).

Önder, N. (2013). Türkiye'de kadın işgücünün görünümü, ÇSGB Çalışma Dünyası Dergisi, 1(1), 3561.

Özbay, F. (1982). Evkadınları, Ekonomik Yaklaşım, 3(7), 209-225.

Özer, M. ve Biçerli, K. (2003) Türkiye'de kadın işgücünün panel veri analizi, Anadolu Üniversitesi Sosyal Bilimler Dergisi, 2003-2004, 3(1), 55-86.

Pekşen Akça, R. (2012). Ana- babaların çocuk yetiştirmede aşırı koruyucu olmaları, Akademik Bakış Dergisi, 29, 1-13.

Sabah (2020). https://www.sabah.com.tr/dunya/2020/03/31/abdden-gelen-son-dakika-coronavirusu-goruntuleri-saskina-cevirdi-doktorlar-hep-birlikte-bunu-yapti (erişim: 30.06.2020) 
Sağl1k Bakanlığı (2020a). https://covid19bilgi.saglik.gov.tr/tr/covid-19-yeni-koronavirus-hastaliginedir (erişim: 30.05 .2020$)$.

Sağlik Bakanlığı (2020b). https://covid19.saglik.gov.tr/ (erişim: 29.06.2020).

Subaşı, N. (2001). Gündelik hayat ve dinsellik, Yüzüncü Yıl Üniversitesi Sosyal Bilimler Enstitüsü Dergisi, 2, 239-267.

TDK (2020). Ev hanımı, https://sozluk.gov.tr/ (erişim: 31.05. 2020).

TÜİK (2015). Zaman kullanım araştırmas1, 2014-2015, Türkiye İstatistik Kurumu Haber Bülteni, Say1:

file:///C:/Users/pc/Downloads/Zaman_Kullan\%C4\%B1m_Ara\%C5\%9Ft\%C4\%B1rmas\%C 4\%B1_04.12.2015.pdf (erişim: 05.01.2020).

Ünal, N. (2012). A comparison of middle and lower middle class housewives, Orta Doğu Teknik Üniversitesi, Sosyal Bilimler Enstitüsü, Sosyoloji Yüksek Lisans Tezi.

Yeni Şafak (2020). https://www.yenisafak.com/dunya/mescid-i-aksada-koronavirus-duasi-birermetre-arayla-saf-tuttular-3530369 (erişim: 30.06.2020). 